Purdue University Purdue e-Pubs

2013

\title{
Professional Development Reflection Journal for Travel Abroad
}

Margaret Sass

Purdue University, sassm@purdue.edu

Follow this and additional works at: https://docs.lib.purdue.edu/sps_ebooks

Part of the Educational Methods Commons

\section{Recommended Citation}

Sass, M. (2013) Professional Development Reflection Journal for Travel Abroad. Center for Instructional Excellence: West Lafayette, IN. $10.5703 / 1288284315192$.

This document has been made available through Purdue e-Pubs, a service of the Purdue University Libraries. Please contact epubs@purdue.edu for additional information. 


\section{SELF-DEVELOPMENT REFLECTION JOURNAL FOR STUDENTS}

Margaret Shu-Mei Sass, EdD, JD






\section{SELF-DEVELOPMENT REFLECTION JOURNAL FOR STUDENTS}

By Margaret Shu-Mei Sass, EdD, JD

(C) 2013 



\section{CONTENTS}

WELCOME TO THE WORLD OF HIGHER ED! 1

PRE-ENTRY REFLECTION 3

THE COLLEGE EXPERIENCE $\quad 5$

TEAMWORK ACTIVITY $\quad 7$

WHAT IS YOUR LEVEL OF CULTURAL COMPETENCE? 9

GOAL SETTING GUIDELINES 11

BUCKET LIST $\quad 13$

PLAN OF ACTION FOR CULTURAL COMPETENCE-LEARNING MORE ABOUT ETHNICITIES $\quad 15$

SELF-DEVELOPMENT DAILY JOURNAL 17

END OF THE YEAR SELF-ANALYSIS 193

OVERALL REFLECTION 195

NOTES 197 



\section{WELCOME TO THE WORLD OF HIGHER ED!}

Welcome to journal for self-development while you are attending college! You are on your way to a great cultural adventure, an academic journey, and a self-reflective voyage. This handbook provides an opportunity for you to understand your own personal and professional path throughout your college experience. You have now entered a new world of opportunity and endless possibilities. Take advantage of this academic expedition and explore!

How this handbook works:

- Complete pre-entry reflection

- Complete the college experience

- Complete multicultural activity

- Fill out "what is your level of cultural competence?"

- Look over goal setting guidelines

- Have fun and fill out the bucket list!

- Complete the plan of action for cultural competence-learning more about ethnicities

- $\quad$ Start the self-development daily journal

- End of the year with the self-analysis and the overall reflection 


\section{PRE-ENTRY REFLECTION}

1. Why did you choose to go to college?

2. When do you plan to graduate?

3. What do you expect to learn about yourself?

4. How does this particular school relate to your career path?

5. What do you think culture shock is?

6. Do you expect to have culture shock once you arrive? Why or why not? 
7. Is there anyone you can talk to about attending this college prior to arrival?

8. How are you preparing to communicate with roommates? Other students? Faculty?

9. What do you know about the school you are attending?

10. What concerns you the most about college?

11. How are you feeling right now about college? 


\section{THE COLLEGE EXPERIENCE}

1. Describe your college campus (1) politically, (2) geographically, and (3) culturally.

2. What do you expect to see once you arrive?

3. What do you plan to visit while you are there?

4. What is your plan of action if you get lost?

5. Where do most students live? 
6. What extracurricular activities are most popular among students?

Research some of the current events occurring on campus. What do you plan on doing in the next 6 months? 


\section{TEAMWORK ACTIVITY}

Listed below are suggested teamwork or individual activities to create a more collaborative and interpersonal environment with other students in your classes, dorm, or clubs:

- Complete a community service project at a food bank, a community center, a school, etc. that represents a population you are unfamiliar with. Think about what you want to accomplish for the organization and for the group.

- Go to a restaurant serving the local cuisine, locally grown fruit and vegetables.

- Watch an inspiring movie at the local movie theatre.

- Volunteer at a cultural center that represents the multicultural make-up of your school.

- Ask another student (junior or senior) to be your mentor that is majoring in the same area.

- Create a blog and/or create an email dialogue with other students in other colleges/universities. Invite others to participate or create a "team" page to blog.

- Attend a special event as a concert, food festival, etc. that may expose you to that culture or other different cultures in the local area. Think about your own ethnicity and how its represented in the community. How is it represented at your school?

- Do a search on YouTube and find videos about your school or the city in which it's located. Are they academic clips? Are some done my students and entertaining? Would you consider creating a YouTube clip for high school students that will attend your college in the near future?

- Join an association or group that supports your favorite hobby.

- Join an association or group that represents your major.

- Volunteer at a local nursing home and learn from the "locals" that retired here.

- Meet another student from a different country and become friends. Learn about each other's culture.

1. What activity did you do?

2. Explain the experience. What did you learn? 


\section{WHAT IS YOUR LEVEL OF CULTURAL COMPETENCE?}

Please read each of the following statements and rate the extent to which you agree with each one of them by using the scale provided ( 1 being low, 5 being high):

1. Rate your level of knowledge on world views.

$\begin{array}{lllll}1 & 2 & 3 & 4 & 5\end{array}$

2. Rate your level of knowledge on different ethnic groups.

$\begin{array}{lllll}1 & 2 & 3 & 4 & 5\end{array}$

3. What is your perception of different cultural groups?

4. What is your perception of different countries?

5. What is your level of interaction with different ethnic groups?

6. What is your attitude towards individuals that do not speak English?

7. Do you seek out individuals different from yourself to learn more about their culture? 
8. What is your knowledge of other cultures? Explain

9. How would you describe your level of respect for other cultures and ethnic groups? What would you like to change regarding your actions toward individuals different from yourself?

10. Do you act different nonverbally with different ethnic groups? 


\section{GOAL SETTING GUIDELINES}

1. List at least 5 goals you would like to accomplish this year.

2. Provide a plan on how you'll meet these goals.

3. What is your reward for each goal? List them.

4. Check off each goal once you meet it and celebrate! 


\section{BUCKET LIST}

Below, list everything you want to accomplish before you die. And I mean everything! Check it off once you've completed.

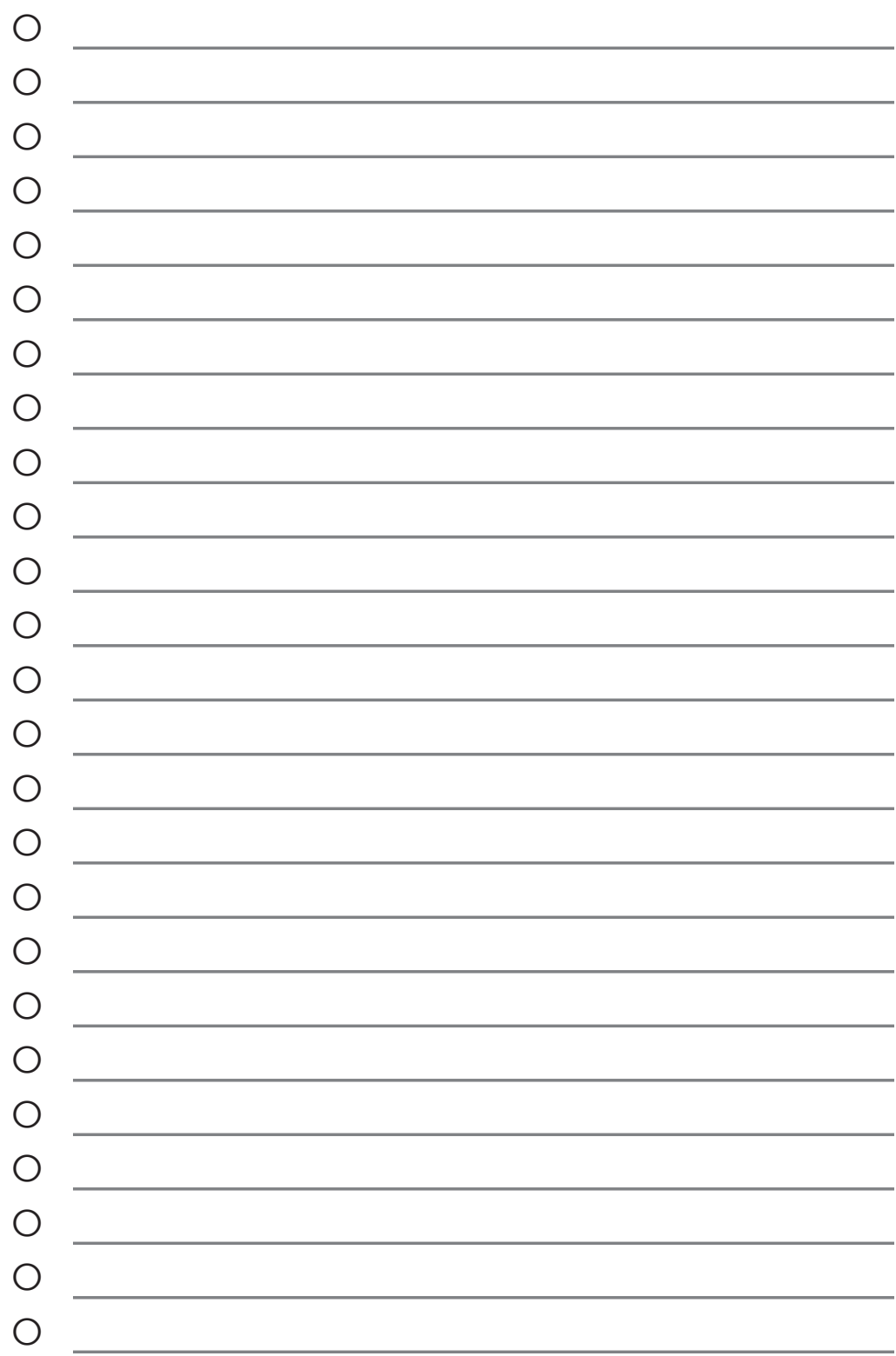




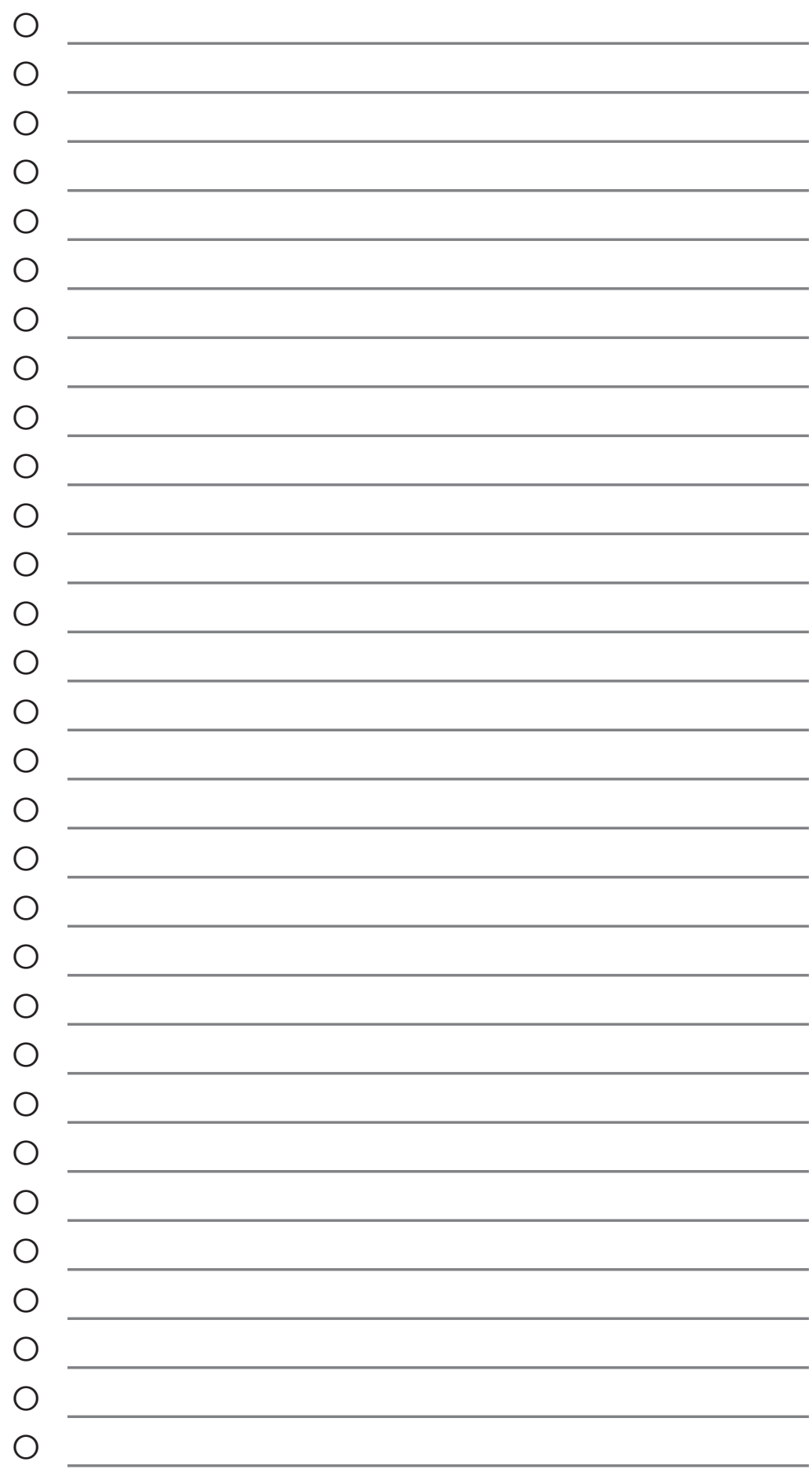




\section{PLAN OF ACTION FOR CULTURAL COMPETENCE- LEARNING MORE ABOUT ETHNICITIES}

In order to be more culturally competent as an individual and as an employee, reflect on how you can become more knowledgeable about different ethnicities and cultures at your school and within the local community.

\begin{tabular}{|c|c|c|}
\hline $\begin{array}{c}\text { AREA OF KNOWLEDGE } \\
\text { TO WORK ON }\end{array}$ & $\begin{array}{c}\text { CURRENT } \\
\text { KNOWLEDGE }\end{array}$ & $\begin{array}{c}\text { ACTIONS TO INCREASE } \\
\text { KNOWLEDGE }\end{array}$ \\
\hline $\begin{array}{c}\text { Ethnicities represented at } \\
\text { your college }\end{array}$ & & \\
$\begin{array}{c}\text { Business etiquette for } \\
\text { different ethnicities }\end{array}$ & & \\
\hline $\begin{array}{c}\text { Religions represented in } \\
\text { the community }\end{array}$ & & \\
\hline $\begin{array}{c}\text { Nonverbal communication } \\
\text { among the } \\
\text { campus and in the } \\
\text { community }\end{array}$ & & \\
different ethnicities & & \\
\hline $\begin{array}{c}\text { Particular gestures } \\
\text { different from your } \\
\text { own culture }\end{array}$ & & \\
\hline & & \\
\hline
\end{tabular}




\begin{tabular}{|c|c|c|}
\hline $\begin{array}{c}\text { AREA OF KNOWLEDGE } \\
\text { TO WORK ON }\end{array}$ & $\begin{array}{c}\text { CURRENT } \\
\text { KNOWLEDGE }\end{array}$ & $\begin{array}{c}\text { ACTIONS TO INCREASE } \\
\text { KNOWLEDGE }\end{array}$ \\
\hline $\begin{array}{c}\text { Geographical location } \\
\text { Local Traditions }\end{array}$ & \\
\hline $\begin{array}{c}\text { Common Language } \\
\text { and Barriers }\end{array}$ & \\
\hline $\begin{array}{c}\text { Climate (business) } \\
\text { (school) }\end{array}$ & \\
\hline $\begin{array}{c}\text { Forms of respect } \\
\text { (businesses) } \\
\text { (schools) }\end{array}$ & & \\
\hline $\begin{array}{c}\text { Formanizational structure of } \\
\text { the college } \\
\text { (businesses) } \\
\text { (schools) } \\
\text { (businesses) }\end{array}$ & & \\
\hline $\begin{array}{c}\text { Climate (weather) } \\
\text { (school) }\end{array}$ & & \\
\hline & & \\
\hline & & \\
\hline
\end{tabular}




\section{SELF-DEVELOPMENT \\ DAILY JOURNAL}

On a scale of $1-5$,

circle the number

that best fits your

thoughts from

strongly disagree (1)

to strongly agree (5)

I am contributing to my professional development.

$$
\begin{array}{lllll}
1 & 2 & 3 & 4 & 5
\end{array}
$$

College allows me to gain a new perspective on my role in life.

\section{$\begin{array}{lllll}1 & 2 & 3 & 4 & 5\end{array}$}

College helps me learn through direct "hands on" experience.

\section{$\begin{array}{lllll}1 & 2 & 3 & 4 & 5\end{array}$}

I feel the college experience will make a difference when working with coworkers, clients, and the community.

$$
\begin{array}{lllll}
1 & 2 & 3 & 4 & 5
\end{array}
$$

I am able to understand my professional role better through the college experience.

\section{$\begin{array}{lllll}1 & 2 & 3 & 4 & 5\end{array}$}

DAY

Describe any significant activities that occurred today.

How did the experiences today affect you academically and personally?

What did you learn about peers today?

How did your activities today relate to your overall goals? 
Is there anything you would do differently today?

What is your goal(s) for tomorrow?

Rate your overall professional experience today (1) poor to (5) great!

Rate your overall academic experience today from (1) poor to (5) great!

Rate your communication skills today from (1) poor to (5) great! 


\section{SELF-DEVELOPMENT \\ DAILY JOURNAL}

On a scale of $1-5$,

circle the number

that best fits your

thoughts from

strongly disagree (1)

to strongly agree (5)

I am contributing to my professional development.

$$
\begin{array}{lllll}
1 & 2 & 3 & 4 & 5
\end{array}
$$

College allows me to gain a new perspective on my role in life.

\section{$\begin{array}{lllll}1 & 2 & 3 & 4 & 5\end{array}$}

College helps me learn through direct "hands on" experience.

\section{$\begin{array}{lllll}1 & 2 & 3 & 4 & 5\end{array}$}

I feel the college experience will make a difference when working with coworkers, clients, and the community.

$$
\begin{array}{lllll}
1 & 2 & 3 & 4 & 5
\end{array}
$$

I am able to understand my professional role better through the college experience.

\section{$\begin{array}{lllll}1 & 2 & 3 & 4 & 5\end{array}$}

DAY

Describe any significant activities that occurred today.

How did the experiences today affect you academically and personally?

What did you learn about peers today?

How did your activities today relate to your overall goals? 
Is there anything you would do differently today?

What is your goal(s) for tomorrow?

Rate your overall professional experience today (1) poor to (5) great!

Rate your overall academic experience today from (1) poor to (5) great!

Rate your communication skills today from (1) poor to (5) great! 


\section{SELF-DEVELOPMENT \\ DAILY JOURNAL}

On a scale of $1-5$,

circle the number

that best fits your

thoughts from

strongly disagree (1)

to strongly agree (5)

I am contributing to my professional development.

$$
\begin{array}{lllll}
1 & 2 & 3 & 4 & 5
\end{array}
$$

College allows me to gain a new perspective on my role in life.

\section{$\begin{array}{lllll}1 & 2 & 3 & 4 & 5\end{array}$}

College helps me learn through direct "hands on" experience.

\section{$\begin{array}{lllll}1 & 2 & 3 & 4 & 5\end{array}$}

I feel the college experience will make a difference when working with coworkers, clients, and the community.

$$
\begin{array}{lllll}
1 & 2 & 3 & 4 & 5
\end{array}
$$

I am able to understand my professional role better through the college experience.

\section{$\begin{array}{lllll}1 & 2 & 3 & 4 & 5\end{array}$}

DAY

Describe any significant activities that occurred today.

How did the experiences today affect you academically and personally?

What did you learn about peers today?

How did your activities today relate to your overall goals? 
Is there anything you would do differently today?

What is your goal(s) for tomorrow?

Rate your overall professional experience today (1) poor to (5) great!

Rate your overall academic experience today from (1) poor to (5) great!

Rate your communication skills today from (1) poor to (5) great! 


\section{SELF-DEVELOPMENT \\ DAILY JOURNAL}

On a scale of $1-5$,

circle the number

that best fits your

thoughts from

strongly disagree (1)

to strongly agree (5)

I am contributing to my professional development.

$$
\begin{array}{lllll}
1 & 2 & 3 & 4 & 5
\end{array}
$$

College allows me to gain a new perspective on my role in life.

\section{$\begin{array}{lllll}1 & 2 & 3 & 4 & 5\end{array}$}

College helps me learn through direct "hands on" experience.

\section{$\begin{array}{lllll}1 & 2 & 3 & 4 & 5\end{array}$}

I feel the college experience will make a difference when working with coworkers, clients, and the community.

$$
\begin{array}{lllll}
1 & 2 & 3 & 4 & 5
\end{array}
$$

I am able to understand my professional role better through the college experience.

\section{$\begin{array}{lllll}1 & 2 & 3 & 4 & 5\end{array}$}

DAY

Describe any significant activities that occurred today.

How did the experiences today affect you academically and personally?

What did you learn about peers today?

How did your activities today relate to your overall goals? 
Is there anything you would do differently today?

What is your goal(s) for tomorrow?

Rate your overall professional experience today (1) poor to (5) great!

Rate your overall academic experience today from (1) poor to (5) great!

Rate your communication skills today from (1) poor to (5) great! 


\section{SELF-DEVELOPMENT \\ DAILY JOURNAL}

On a scale of $1-5$,

circle the number

that best fits your

thoughts from

strongly disagree (1)

to strongly agree (5)

I am contributing to my professional development.

$$
\begin{array}{lllll}
1 & 2 & 3 & 4 & 5
\end{array}
$$

College allows me to gain a new perspective on my role in life.

\section{$\begin{array}{lllll}1 & 2 & 3 & 4 & 5\end{array}$}

College helps me learn through direct "hands on" experience.

\section{$\begin{array}{lllll}1 & 2 & 3 & 4 & 5\end{array}$}

I feel the college experience will make a difference when working with coworkers, clients, and the community.

$$
\begin{array}{lllll}
1 & 2 & 3 & 4 & 5
\end{array}
$$

I am able to understand my professional role better through the college experience.

\section{$\begin{array}{lllll}1 & 2 & 3 & 4 & 5\end{array}$}

DAY

Describe any significant activities that occurred today.

How did the experiences today affect you academically and personally?

What did you learn about peers today?

How did your activities today relate to your overall goals? 
Is there anything you would do differently today?

What is your goal(s) for tomorrow?

Rate your overall professional experience today (1) poor to (5) great!

Rate your overall academic experience today from (1) poor to (5) great!

Rate your communication skills today from (1) poor to (5) great! 


\section{SELF-DEVELOPMENT \\ DAILY JOURNAL}

On a scale of $1-5$,

circle the number

that best fits your

thoughts from

strongly disagree (1)

to strongly agree (5)

I am contributing to my professional development.

$$
\begin{array}{lllll}
1 & 2 & 3 & 4 & 5
\end{array}
$$

College allows me to gain a new perspective on my role in life.

\section{$\begin{array}{lllll}1 & 2 & 3 & 4 & 5\end{array}$}

College helps me learn through direct "hands on" experience.

\section{$\begin{array}{lllll}1 & 2 & 3 & 4 & 5\end{array}$}

I feel the college experience will make a difference when working with coworkers, clients, and the community.

$$
\begin{array}{lllll}
1 & 2 & 3 & 4 & 5
\end{array}
$$

I am able to understand my professional role better through the college experience.

\section{$\begin{array}{lllll}1 & 2 & 3 & 4 & 5\end{array}$}

DAY

Describe any significant activities that occurred today.

How did the experiences today affect you academically and personally?

What did you learn about peers today?

How did your activities today relate to your overall goals? 
Is there anything you would do differently today?

What is your goal(s) for tomorrow?

Rate your overall professional experience today (1) poor to (5) great!

Rate your overall academic experience today from (1) poor to (5) great!

Rate your communication skills today from (1) poor to (5) great! 


\section{SELF-DEVELOPMENT \\ DAILY JOURNAL}

On a scale of $1-5$,

circle the number

that best fits your

thoughts from

strongly disagree (1)

to strongly agree (5)

I am contributing to my professional development.

$$
\begin{array}{lllll}
1 & 2 & 3 & 4 & 5
\end{array}
$$

College allows me to gain a new perspective on my role in life.

\section{$\begin{array}{lllll}1 & 2 & 3 & 4 & 5\end{array}$}

College helps me learn through direct "hands on" experience.

\section{$\begin{array}{lllll}1 & 2 & 3 & 4 & 5\end{array}$}

I feel the college experience will make a difference when working with coworkers, clients, and the community.

$$
\begin{array}{lllll}
1 & 2 & 3 & 4 & 5
\end{array}
$$

I am able to understand my professional role better through the college experience.

\section{$\begin{array}{lllll}1 & 2 & 3 & 4 & 5\end{array}$}

DAY

Describe any significant activities that occurred today.

How did the experiences today affect you academically and personally?

What did you learn about peers today?

How did your activities today relate to your overall goals? 
Is there anything you would do differently today?

What is your goal(s) for tomorrow?

Rate your overall professional experience today (1) poor to (5) great!

Rate your overall academic experience today from (1) poor to (5) great!

Rate your communication skills today from (1) poor to (5) great! 


\section{SELF-DEVELOPMENT \\ DAILY JOURNAL}

On a scale of $1-5$,

circle the number

that best fits your

thoughts from

strongly disagree (1)

to strongly agree (5)

I am contributing to my professional development.

$$
\begin{array}{lllll}
1 & 2 & 3 & 4 & 5
\end{array}
$$

College allows me to gain a new perspective on my role in life.

\section{$\begin{array}{lllll}1 & 2 & 3 & 4 & 5\end{array}$}

College helps me learn through direct "hands on" experience.

\section{$\begin{array}{lllll}1 & 2 & 3 & 4 & 5\end{array}$}

I feel the college experience will make a difference when working with coworkers, clients, and the community.

$$
\begin{array}{lllll}
1 & 2 & 3 & 4 & 5
\end{array}
$$

I am able to understand my professional role better through the college experience.

\section{$\begin{array}{lllll}1 & 2 & 3 & 4 & 5\end{array}$}

DAY

Describe any significant activities that occurred today.

How did the experiences today affect you academically and personally?

What did you learn about peers today?

How did your activities today relate to your overall goals? 
Is there anything you would do differently today?

What is your goal(s) for tomorrow?

Rate your overall professional experience today (1) poor to (5) great!

Rate your overall academic experience today from (1) poor to (5) great!

Rate your communication skills today from (1) poor to (5) great! 


\section{SELF-DEVELOPMENT \\ DAILY JOURNAL}

On a scale of $1-5$,

circle the number

that best fits your

thoughts from

strongly disagree (1)

to strongly agree (5)

I am contributing to my professional development.

$$
\begin{array}{lllll}
1 & 2 & 3 & 4 & 5
\end{array}
$$

College allows me to gain a new perspective on my role in life.

\section{$\begin{array}{lllll}1 & 2 & 3 & 4 & 5\end{array}$}

College helps me learn through direct "hands on" experience.

\section{$\begin{array}{lllll}1 & 2 & 3 & 4 & 5\end{array}$}

I feel the college experience will make a difference when working with coworkers, clients, and the community.

$$
\begin{array}{lllll}
1 & 2 & 3 & 4 & 5
\end{array}
$$

I am able to understand my professional role better through the college experience.

\section{$\begin{array}{lllll}1 & 2 & 3 & 4 & 5\end{array}$}

DAY

Describe any significant activities that occurred today.

How did the experiences today affect you academically and personally?

What did you learn about peers today?

How did your activities today relate to your overall goals? 
Is there anything you would do differently today?

What is your goal(s) for tomorrow?

Rate your overall professional experience today (1) poor to (5) great!

Rate your overall academic experience today from (1) poor to (5) great!

Rate your communication skills today from (1) poor to (5) great! 


\section{SELF-DEVELOPMENT \\ DAILY JOURNAL}

On a scale of $1-5$,

circle the number

that best fits your

thoughts from

strongly disagree (1)

to strongly agree (5)

I am contributing to my professional development.

$$
\begin{array}{lllll}
1 & 2 & 3 & 4 & 5
\end{array}
$$

College allows me to gain a new perspective on my role in life.

\section{$\begin{array}{lllll}1 & 2 & 3 & 4 & 5\end{array}$}

College helps me learn through direct "hands on" experience.

\section{$\begin{array}{lllll}1 & 2 & 3 & 4 & 5\end{array}$}

I feel the college experience will make a difference when working with coworkers, clients, and the community.

$$
\begin{array}{lllll}
1 & 2 & 3 & 4 & 5
\end{array}
$$

I am able to understand my professional role better through the college experience.

\section{$\begin{array}{lllll}1 & 2 & 3 & 4 & 5\end{array}$}

DAY

Describe any significant activities that occurred today.

How did the experiences today affect you academically and personally?

What did you learn about peers today?

How did your activities today relate to your overall goals? 
Is there anything you would do differently today?

What is your goal(s) for tomorrow?

Rate your overall professional experience today (1) poor to (5) great!

Rate your overall academic experience today from (1) poor to (5) great!

Rate your communication skills today from (1) poor to (5) great! 


\section{SELF-DEVELOPMENT \\ DAILY JOURNAL}

On a scale of $1-5$,

circle the number

that best fits your

thoughts from

strongly disagree (1)

to strongly agree (5)

I am contributing to my professional development.

$$
\begin{array}{lllll}
1 & 2 & 3 & 4 & 5
\end{array}
$$

College allows me to gain a new perspective on my role in life.

\section{$\begin{array}{lllll}1 & 2 & 3 & 4 & 5\end{array}$}

College helps me learn through direct "hands on" experience.

\section{$\begin{array}{lllll}1 & 2 & 3 & 4 & 5\end{array}$}

I feel the college experience will make a difference when working with coworkers, clients, and the community.

$$
\begin{array}{lllll}
1 & 2 & 3 & 4 & 5
\end{array}
$$

I am able to understand my professional role better through the college experience.

\section{$\begin{array}{lllll}1 & 2 & 3 & 4 & 5\end{array}$}

DAY

Describe any significant activities that occurred today.

How did the experiences today affect you academically and personally?

What did you learn about peers today?

How did your activities today relate to your overall goals? 
Is there anything you would do differently today?

What is your goal(s) for tomorrow?

Rate your overall professional experience today (1) poor to (5) great!

Rate your overall academic experience today from (1) poor to (5) great!

Rate your communication skills today from (1) poor to (5) great! 


\section{SELF-DEVELOPMENT \\ DAILY JOURNAL}

On a scale of $1-5$,

circle the number

that best fits your

thoughts from

strongly disagree (1)

to strongly agree (5)

I am contributing to my professional development.

$$
\begin{array}{lllll}
1 & 2 & 3 & 4 & 5
\end{array}
$$

College allows me to gain a new perspective on my role in life.

\section{$\begin{array}{lllll}1 & 2 & 3 & 4 & 5\end{array}$}

College helps me learn through direct "hands on" experience.

\section{$\begin{array}{lllll}1 & 2 & 3 & 4 & 5\end{array}$}

I feel the college experience will make a difference when working with coworkers, clients, and the community.

$$
\begin{array}{lllll}
1 & 2 & 3 & 4 & 5
\end{array}
$$

I am able to understand my professional role better through the college experience.

\section{$\begin{array}{lllll}1 & 2 & 3 & 4 & 5\end{array}$}

DAY

Describe any significant activities that occurred today.

How did the experiences today affect you academically and personally?

What did you learn about peers today?

How did your activities today relate to your overall goals? 
Is there anything you would do differently today?

What is your goal(s) for tomorrow?

Rate your overall professional experience today (1) poor to (5) great!

Rate your overall academic experience today from (1) poor to (5) great!

Rate your communication skills today from (1) poor to (5) great! 


\section{SELF-DEVELOPMENT \\ DAILY JOURNAL}

On a scale of $1-5$,

circle the number

that best fits your

thoughts from

strongly disagree (1)

to strongly agree (5)

I am contributing to my professional development.

$$
\begin{array}{lllll}
1 & 2 & 3 & 4 & 5
\end{array}
$$

College allows me to gain a new perspective on my role in life.

\section{$\begin{array}{lllll}1 & 2 & 3 & 4 & 5\end{array}$}

College helps me learn through direct "hands on" experience.

\section{$\begin{array}{lllll}1 & 2 & 3 & 4 & 5\end{array}$}

I feel the college experience will make a difference when working with coworkers, clients, and the community.

$$
\begin{array}{lllll}
1 & 2 & 3 & 4 & 5
\end{array}
$$

I am able to understand my professional role better through the college experience.

\section{$\begin{array}{lllll}1 & 2 & 3 & 4 & 5\end{array}$}

DAY

Describe any significant activities that occurred today.

How did the experiences today affect you academically and personally?

What did you learn about peers today?

How did your activities today relate to your overall goals? 
Is there anything you would do differently today?

What is your goal(s) for tomorrow?

Rate your overall professional experience today (1) poor to (5) great!

Rate your overall academic experience today from (1) poor to (5) great!

Rate your communication skills today from (1) poor to (5) great! 


\section{SELF-DEVELOPMENT \\ DAILY JOURNAL}

On a scale of $1-5$,

circle the number

that best fits your

thoughts from

strongly disagree (1)

to strongly agree (5)

I am contributing to my professional development.

$$
\begin{array}{lllll}
1 & 2 & 3 & 4 & 5
\end{array}
$$

College allows me to gain a new perspective on my role in life.

\section{$\begin{array}{lllll}1 & 2 & 3 & 4 & 5\end{array}$}

College helps me learn through direct "hands on" experience.

\section{$\begin{array}{lllll}1 & 2 & 3 & 4 & 5\end{array}$}

I feel the college experience will make a difference when working with coworkers, clients, and the community.

$$
\begin{array}{lllll}
1 & 2 & 3 & 4 & 5
\end{array}
$$

I am able to understand my professional role better through the college experience.

\section{$\begin{array}{lllll}1 & 2 & 3 & 4 & 5\end{array}$}

DAY

Describe any significant activities that occurred today.

How did the experiences today affect you academically and personally?

What did you learn about peers today?

How did your activities today relate to your overall goals? 
Is there anything you would do differently today?

What is your goal(s) for tomorrow?

Rate your overall professional experience today (1) poor to (5) great!

Rate your overall academic experience today from (1) poor to (5) great!

Rate your communication skills today from (1) poor to (5) great! 


\section{SELF-DEVELOPMENT \\ DAILY JOURNAL}

On a scale of $1-5$,

circle the number

that best fits your

thoughts from

strongly disagree (1)

to strongly agree (5)

I am contributing to my professional development.

$$
\begin{array}{lllll}
1 & 2 & 3 & 4 & 5
\end{array}
$$

College allows me to gain a new perspective on my role in life.

\section{$\begin{array}{lllll}1 & 2 & 3 & 4 & 5\end{array}$}

College helps me learn through direct "hands on" experience.

\section{$\begin{array}{lllll}1 & 2 & 3 & 4 & 5\end{array}$}

I feel the college experience will make a difference when working with coworkers, clients, and the community.

$$
\begin{array}{lllll}
1 & 2 & 3 & 4 & 5
\end{array}
$$

I am able to understand my professional role better through the college experience.

\section{$\begin{array}{lllll}1 & 2 & 3 & 4 & 5\end{array}$}

DAY

Describe any significant activities that occurred today.

How did the experiences today affect you academically and personally?

What did you learn about peers today?

How did your activities today relate to your overall goals? 
Is there anything you would do differently today?

What is your goal(s) for tomorrow?

Rate your overall professional experience today (1) poor to (5) great!

Rate your overall academic experience today from (1) poor to (5) great!

Rate your communication skills today from (1) poor to (5) great! 


\section{SELF-DEVELOPMENT \\ DAILY JOURNAL}

On a scale of $1-5$,

circle the number

that best fits your

thoughts from

strongly disagree (1)

to strongly agree (5)

I am contributing to my professional development.

$$
\begin{array}{lllll}
1 & 2 & 3 & 4 & 5
\end{array}
$$

College allows me to gain a new perspective on my role in life.

\section{$\begin{array}{lllll}1 & 2 & 3 & 4 & 5\end{array}$}

College helps me learn through direct "hands on" experience.

\section{$\begin{array}{lllll}1 & 2 & 3 & 4 & 5\end{array}$}

I feel the college experience will make a difference when working with coworkers, clients, and the community.

$$
\begin{array}{lllll}
1 & 2 & 3 & 4 & 5
\end{array}
$$

I am able to understand my professional role better through the college experience.

\section{$\begin{array}{lllll}1 & 2 & 3 & 4 & 5\end{array}$}

DAY

Describe any significant activities that occurred today.

How did the experiences today affect you academically and personally?

What did you learn about peers today?

How did your activities today relate to your overall goals? 
Is there anything you would do differently today?

What is your goal(s) for tomorrow?

Rate your overall professional experience today (1) poor to (5) great!

Rate your overall academic experience today from (1) poor to (5) great!

Rate your communication skills today from (1) poor to (5) great! 


\section{SELF-DEVELOPMENT \\ DAILY JOURNAL}

On a scale of $1-5$,

circle the number

that best fits your

thoughts from

strongly disagree (1)

to strongly agree (5)

I am contributing to my professional development.

$$
\begin{array}{lllll}
1 & 2 & 3 & 4 & 5
\end{array}
$$

College allows me to gain a new perspective on my role in life.

\section{$\begin{array}{lllll}1 & 2 & 3 & 4 & 5\end{array}$}

College helps me learn through direct "hands on" experience.

\section{$\begin{array}{lllll}1 & 2 & 3 & 4 & 5\end{array}$}

I feel the college experience will make a difference when working with coworkers, clients, and the community.

$$
\begin{array}{lllll}
1 & 2 & 3 & 4 & 5
\end{array}
$$

I am able to understand my professional role better through the college experience.

\section{$\begin{array}{lllll}1 & 2 & 3 & 4 & 5\end{array}$}

DAY

Describe any significant activities that occurred today.

How did the experiences today affect you academically and personally?

What did you learn about peers today?

How did your activities today relate to your overall goals? 
Is there anything you would do differently today?

What is your goal(s) for tomorrow?

Rate your overall professional experience today (1) poor to (5) great!

Rate your overall academic experience today from (1) poor to (5) great!

Rate your communication skills today from (1) poor to (5) great! 


\section{SELF-DEVELOPMENT \\ DAILY JOURNAL}

On a scale of $1-5$,

circle the number

that best fits your

thoughts from

strongly disagree (1)

to strongly agree (5)

I am contributing to my professional development.

$$
\begin{array}{lllll}
1 & 2 & 3 & 4 & 5
\end{array}
$$

College allows me to gain a new perspective on my role in life.

\section{$\begin{array}{lllll}1 & 2 & 3 & 4 & 5\end{array}$}

College helps me learn through direct "hands on" experience.

\section{$\begin{array}{lllll}1 & 2 & 3 & 4 & 5\end{array}$}

I feel the college experience will make a difference when working with coworkers, clients, and the community.

$$
\begin{array}{lllll}
1 & 2 & 3 & 4 & 5
\end{array}
$$

I am able to understand my professional role better through the college experience.

\section{$\begin{array}{lllll}1 & 2 & 3 & 4 & 5\end{array}$}

DAY

Describe any significant activities that occurred today.

How did the experiences today affect you academically and personally?

What did you learn about peers today?

How did your activities today relate to your overall goals? 
Is there anything you would do differently today?

What is your goal(s) for tomorrow?

Rate your overall professional experience today (1) poor to (5) great!

Rate your overall academic experience today from (1) poor to (5) great!

Rate your communication skills today from (1) poor to (5) great! 


\section{SELF-DEVELOPMENT \\ DAILY JOURNAL}

On a scale of $1-5$,

circle the number

that best fits your

thoughts from

strongly disagree (1)

to strongly agree (5)

I am contributing to my professional development.

$$
\begin{array}{lllll}
1 & 2 & 3 & 4 & 5
\end{array}
$$

College allows me to gain a new perspective on my role in life.

\section{$\begin{array}{lllll}1 & 2 & 3 & 4 & 5\end{array}$}

College helps me learn through direct "hands on" experience.

\section{$\begin{array}{lllll}1 & 2 & 3 & 4 & 5\end{array}$}

I feel the college experience will make a difference when working with coworkers, clients, and the community.

$$
\begin{array}{lllll}
1 & 2 & 3 & 4 & 5
\end{array}
$$

I am able to understand my professional role better through the college experience.

\section{$\begin{array}{lllll}1 & 2 & 3 & 4 & 5\end{array}$}

DAY

Describe any significant activities that occurred today.

How did the experiences today affect you academically and personally?

What did you learn about peers today?

How did your activities today relate to your overall goals? 
Is there anything you would do differently today?

What is your goal(s) for tomorrow?

Rate your overall professional experience today (1) poor to (5) great!

Rate your overall academic experience today from (1) poor to (5) great!

Rate your communication skills today from (1) poor to (5) great! 


\section{SELF-DEVELOPMENT \\ DAILY JOURNAL}

On a scale of $1-5$,

circle the number

that best fits your

thoughts from

strongly disagree (1)

to strongly agree (5)

I am contributing to my professional development.

$$
\begin{array}{lllll}
1 & 2 & 3 & 4 & 5
\end{array}
$$

College allows me to gain a new perspective on my role in life.

\section{$\begin{array}{lllll}1 & 2 & 3 & 4 & 5\end{array}$}

College helps me learn through direct "hands on" experience.

\section{$\begin{array}{lllll}1 & 2 & 3 & 4 & 5\end{array}$}

I feel the college experience will make a difference when working with coworkers, clients, and the community.

$$
\begin{array}{lllll}
1 & 2 & 3 & 4 & 5
\end{array}
$$

I am able to understand my professional role better through the college experience.

\section{$\begin{array}{lllll}1 & 2 & 3 & 4 & 5\end{array}$}

DAY

Describe any significant activities that occurred today.

How did the experiences today affect you academically and personally?

What did you learn about peers today?

How did your activities today relate to your overall goals? 
Is there anything you would do differently today?

What is your goal(s) for tomorrow?

Rate your overall professional experience today (1) poor to (5) great!

Rate your overall academic experience today from (1) poor to (5) great!

Rate your communication skills today from (1) poor to (5) great! 


\section{SELF-DEVELOPMENT \\ DAILY JOURNAL}

On a scale of $1-5$,

circle the number

that best fits your

thoughts from

strongly disagree (1)

to strongly agree (5)

I am contributing to my professional development.

$$
\begin{array}{lllll}
1 & 2 & 3 & 4 & 5
\end{array}
$$

College allows me to gain a new perspective on my role in life.

\section{$\begin{array}{lllll}1 & 2 & 3 & 4 & 5\end{array}$}

College helps me learn through direct "hands on" experience.

\section{$\begin{array}{lllll}1 & 2 & 3 & 4 & 5\end{array}$}

I feel the college experience will make a difference when working with coworkers, clients, and the community.

$$
\begin{array}{lllll}
1 & 2 & 3 & 4 & 5
\end{array}
$$

I am able to understand my professional role better through the college experience.

\section{$\begin{array}{lllll}1 & 2 & 3 & 4 & 5\end{array}$}

DAY

Describe any significant activities that occurred today.

How did the experiences today affect you academically and personally?

What did you learn about peers today?

How did your activities today relate to your overall goals? 
Is there anything you would do differently today?

What is your goal(s) for tomorrow?

Rate your overall professional experience today (1) poor to (5) great!

Rate your overall academic experience today from (1) poor to (5) great!

Rate your communication skills today from (1) poor to (5) great! 


\section{SELF-DEVELOPMENT \\ DAILY JOURNAL}

On a scale of $1-5$,

circle the number

that best fits your

thoughts from

strongly disagree (1)

to strongly agree (5)

I am contributing to my professional development.

$$
\begin{array}{lllll}
1 & 2 & 3 & 4 & 5
\end{array}
$$

College allows me to gain a new perspective on my role in life.

\section{$\begin{array}{lllll}1 & 2 & 3 & 4 & 5\end{array}$}

College helps me learn through direct "hands on" experience.

\section{$\begin{array}{lllll}1 & 2 & 3 & 4 & 5\end{array}$}

I feel the college experience will make a difference when working with coworkers, clients, and the community.

$$
\begin{array}{lllll}
1 & 2 & 3 & 4 & 5
\end{array}
$$

I am able to understand my professional role better through the college experience.

\section{$\begin{array}{lllll}1 & 2 & 3 & 4 & 5\end{array}$}

DAY

Describe any significant activities that occurred today.

How did the experiences today affect you academically and personally?

What did you learn about peers today?

How did your activities today relate to your overall goals? 
Is there anything you would do differently today?

What is your goal(s) for tomorrow?

Rate your overall professional experience today (1) poor to (5) great!

Rate your overall academic experience today from (1) poor to (5) great!

Rate your communication skills today from (1) poor to (5) great! 


\section{SELF-DEVELOPMENT \\ DAILY JOURNAL}

On a scale of $1-5$,

circle the number

that best fits your

thoughts from

strongly disagree (1)

to strongly agree (5)

I am contributing to my professional development.

$$
\begin{array}{lllll}
1 & 2 & 3 & 4 & 5
\end{array}
$$

College allows me to gain a new perspective on my role in life.

\section{$\begin{array}{lllll}1 & 2 & 3 & 4 & 5\end{array}$}

College helps me learn through direct "hands on" experience.

\section{$\begin{array}{lllll}1 & 2 & 3 & 4 & 5\end{array}$}

I feel the college experience will make a difference when working with coworkers, clients, and the community.

$$
\begin{array}{lllll}
1 & 2 & 3 & 4 & 5
\end{array}
$$

I am able to understand my professional role better through the college experience.

\section{$\begin{array}{lllll}1 & 2 & 3 & 4 & 5\end{array}$}

DAY

Describe any significant activities that occurred today.

How did the experiences today affect you academically and personally?

What did you learn about peers today?

How did your activities today relate to your overall goals? 
Is there anything you would do differently today?

What is your goal(s) for tomorrow?

Rate your overall professional experience today (1) poor to (5) great!

Rate your overall academic experience today from (1) poor to (5) great!

Rate your communication skills today from (1) poor to (5) great! 


\section{SELF-DEVELOPMENT \\ DAILY JOURNAL}

On a scale of $1-5$,

circle the number

that best fits your

thoughts from

strongly disagree (1)

to strongly agree (5)

I am contributing to my professional development.

$$
\begin{array}{lllll}
1 & 2 & 3 & 4 & 5
\end{array}
$$

College allows me to gain a new perspective on my role in life.

\section{$\begin{array}{lllll}1 & 2 & 3 & 4 & 5\end{array}$}

College helps me learn through direct "hands on" experience.

\section{$\begin{array}{lllll}1 & 2 & 3 & 4 & 5\end{array}$}

I feel the college experience will make a difference when working with coworkers, clients, and the community.

$$
\begin{array}{lllll}
1 & 2 & 3 & 4 & 5
\end{array}
$$

I am able to understand my professional role better through the college experience.

\section{$\begin{array}{lllll}1 & 2 & 3 & 4 & 5\end{array}$}

DAY

Describe any significant activities that occurred today.

How did the experiences today affect you academically and personally?

What did you learn about peers today?

How did your activities today relate to your overall goals? 
Is there anything you would do differently today?

What is your goal(s) for tomorrow?

Rate your overall professional experience today (1) poor to (5) great!

Rate your overall academic experience today from (1) poor to (5) great!

Rate your communication skills today from (1) poor to (5) great! 


\section{SELF-DEVELOPMENT \\ DAILY JOURNAL}

On a scale of $1-5$,

circle the number

that best fits your

thoughts from

strongly disagree (1)

to strongly agree (5)

I am contributing to my professional development.

$$
\begin{array}{lllll}
1 & 2 & 3 & 4 & 5
\end{array}
$$

College allows me to gain a new perspective on my role in life.

\section{$\begin{array}{lllll}1 & 2 & 3 & 4 & 5\end{array}$}

College helps me learn through direct "hands on" experience.

\section{$\begin{array}{lllll}1 & 2 & 3 & 4 & 5\end{array}$}

I feel the college experience will make a difference when working with coworkers, clients, and the community.

$$
\begin{array}{lllll}
1 & 2 & 3 & 4 & 5
\end{array}
$$

I am able to understand my professional role better through the college experience.

\section{$\begin{array}{lllll}1 & 2 & 3 & 4 & 5\end{array}$}

DAY

Describe any significant activities that occurred today.

How did the experiences today affect you academically and personally?

What did you learn about peers today?

How did your activities today relate to your overall goals? 
Is there anything you would do differently today?

What is your goal(s) for tomorrow?

Rate your overall professional experience today (1) poor to (5) great!

Rate your overall academic experience today from (1) poor to (5) great!

Rate your communication skills today from (1) poor to (5) great! 


\section{SELF-DEVELOPMENT \\ DAILY JOURNAL}

On a scale of $1-5$,

circle the number

that best fits your

thoughts from

strongly disagree (1)

to strongly agree (5)

I am contributing to my professional development.

$$
\begin{array}{lllll}
1 & 2 & 3 & 4 & 5
\end{array}
$$

College allows me to gain a new perspective on my role in life.

\section{$\begin{array}{lllll}1 & 2 & 3 & 4 & 5\end{array}$}

College helps me learn through direct "hands on" experience.

\section{$\begin{array}{lllll}1 & 2 & 3 & 4 & 5\end{array}$}

I feel the college experience will make a difference when working with coworkers, clients, and the community.

$$
\begin{array}{lllll}
1 & 2 & 3 & 4 & 5
\end{array}
$$

I am able to understand my professional role better through the college experience.

\section{$\begin{array}{lllll}1 & 2 & 3 & 4 & 5\end{array}$}

DAY

Describe any significant activities that occurred today.

How did the experiences today affect you academically and personally?

What did you learn about peers today?

How did your activities today relate to your overall goals? 
Is there anything you would do differently today?

What is your goal(s) for tomorrow?

Rate your overall professional experience today (1) poor to (5) great!

Rate your overall academic experience today from (1) poor to (5) great!

Rate your communication skills today from (1) poor to (5) great! 


\section{SELF-DEVELOPMENT \\ DAILY JOURNAL}

On a scale of $1-5$,

circle the number

that best fits your

thoughts from

strongly disagree (1)

to strongly agree (5)

I am contributing to my professional development.

$$
\begin{array}{lllll}
1 & 2 & 3 & 4 & 5
\end{array}
$$

College allows me to gain a new perspective on my role in life.

\section{$\begin{array}{lllll}1 & 2 & 3 & 4 & 5\end{array}$}

College helps me learn through direct "hands on" experience.

\section{$\begin{array}{lllll}1 & 2 & 3 & 4 & 5\end{array}$}

I feel the college experience will make a difference when working with coworkers, clients, and the community.

$$
\begin{array}{lllll}
1 & 2 & 3 & 4 & 5
\end{array}
$$

I am able to understand my professional role better through the college experience.

\section{$\begin{array}{lllll}1 & 2 & 3 & 4 & 5\end{array}$}

DAY

Describe any significant activities that occurred today.

How did the experiences today affect you academically and personally?

What did you learn about peers today?

How did your activities today relate to your overall goals? 
Is there anything you would do differently today?

What is your goal(s) for tomorrow?

Rate your overall professional experience today (1) poor to (5) great!

Rate your overall academic experience today from (1) poor to (5) great!

Rate your communication skills today from (1) poor to (5) great! 


\section{SELF-DEVELOPMENT \\ DAILY JOURNAL}

On a scale of $1-5$,

circle the number

that best fits your

thoughts from

strongly disagree (1)

to strongly agree (5)

I am contributing to my professional development.

$$
\begin{array}{lllll}
1 & 2 & 3 & 4 & 5
\end{array}
$$

College allows me to gain a new perspective on my role in life.

\section{$\begin{array}{lllll}1 & 2 & 3 & 4 & 5\end{array}$}

College helps me learn through direct "hands on" experience.

\section{$\begin{array}{lllll}1 & 2 & 3 & 4 & 5\end{array}$}

I feel the college experience will make a difference when working with coworkers, clients, and the community.

$$
\begin{array}{lllll}
1 & 2 & 3 & 4 & 5
\end{array}
$$

I am able to understand my professional role better through the college experience.

\section{$\begin{array}{lllll}1 & 2 & 3 & 4 & 5\end{array}$}

DAY

Describe any significant activities that occurred today.

How did the experiences today affect you academically and personally?

What did you learn about peers today?

How did your activities today relate to your overall goals? 
Is there anything you would do differently today?

What is your goal(s) for tomorrow?

Rate your overall professional experience today (1) poor to (5) great!

Rate your overall academic experience today from (1) poor to (5) great!

Rate your communication skills today from (1) poor to (5) great! 


\section{SELF-DEVELOPMENT \\ DAILY JOURNAL}

On a scale of $1-5$,

circle the number

that best fits your

thoughts from

strongly disagree (1)

to strongly agree (5)

I am contributing to my professional development.

$$
\begin{array}{lllll}
1 & 2 & 3 & 4 & 5
\end{array}
$$

College allows me to gain a new perspective on my role in life.

\section{$\begin{array}{lllll}1 & 2 & 3 & 4 & 5\end{array}$}

College helps me learn through direct "hands on" experience.

\section{$\begin{array}{lllll}1 & 2 & 3 & 4 & 5\end{array}$}

I feel the college experience will make a difference when working with coworkers, clients, and the community.

$$
\begin{array}{lllll}
1 & 2 & 3 & 4 & 5
\end{array}
$$

I am able to understand my professional role better through the college experience.

\section{$\begin{array}{lllll}1 & 2 & 3 & 4 & 5\end{array}$}

DAY

Describe any significant activities that occurred today.

How did the experiences today affect you academically and personally?

What did you learn about peers today?

How did your activities today relate to your overall goals? 
Is there anything you would do differently today?

What is your goal(s) for tomorrow?

Rate your overall professional experience today (1) poor to (5) great!

Rate your overall academic experience today from (1) poor to (5) great!

Rate your communication skills today from (1) poor to (5) great! 


\section{SELF-DEVELOPMENT \\ DAILY JOURNAL}

On a scale of $1-5$,

circle the number

that best fits your

thoughts from

strongly disagree (1)

to strongly agree (5)

I am contributing to my professional development.

$$
\begin{array}{lllll}
1 & 2 & 3 & 4 & 5
\end{array}
$$

College allows me to gain a new perspective on my role in life.

\section{$\begin{array}{lllll}1 & 2 & 3 & 4 & 5\end{array}$}

College helps me learn through direct "hands on" experience.

\section{$\begin{array}{lllll}1 & 2 & 3 & 4 & 5\end{array}$}

I feel the college experience will make a difference when working with coworkers, clients, and the community.

$$
\begin{array}{lllll}
1 & 2 & 3 & 4 & 5
\end{array}
$$

I am able to understand my professional role better through the college experience.

\section{$\begin{array}{lllll}1 & 2 & 3 & 4 & 5\end{array}$}

DAY

Describe any significant activities that occurred today.

How did the experiences today affect you academically and personally?

What did you learn about peers today?

How did your activities today relate to your overall goals? 
Is there anything you would do differently today?

What is your goal(s) for tomorrow?

Rate your overall professional experience today (1) poor to (5) great!

Rate your overall academic experience today from (1) poor to (5) great!

Rate your communication skills today from (1) poor to (5) great! 


\section{SELF-DEVELOPMENT \\ DAILY JOURNAL}

On a scale of $1-5$,

circle the number

that best fits your

thoughts from

strongly disagree (1)

to strongly agree (5)

I am contributing to my professional development.

$$
\begin{array}{lllll}
1 & 2 & 3 & 4 & 5
\end{array}
$$

College allows me to gain a new perspective on my role in life.

\section{$\begin{array}{lllll}1 & 2 & 3 & 4 & 5\end{array}$}

College helps me learn through direct "hands on" experience.

\section{$\begin{array}{lllll}1 & 2 & 3 & 4 & 5\end{array}$}

I feel the college experience will make a difference when working with coworkers, clients, and the community.

$$
\begin{array}{lllll}
1 & 2 & 3 & 4 & 5
\end{array}
$$

I am able to understand my professional role better through the college experience.

\section{$\begin{array}{lllll}1 & 2 & 3 & 4 & 5\end{array}$}

DAY

Describe any significant activities that occurred today.

How did the experiences today affect you academically and personally?

What did you learn about peers today?

How did your activities today relate to your overall goals? 
Is there anything you would do differently today?

What is your goal(s) for tomorrow?

Rate your overall professional experience today (1) poor to (5) great!

Rate your overall academic experience today from (1) poor to (5) great!

Rate your communication skills today from (1) poor to (5) great! 


\section{SELF-DEVELOPMENT \\ DAILY JOURNAL}

On a scale of $1-5$,

circle the number

that best fits your

thoughts from

strongly disagree (1)

to strongly agree (5)

I am contributing to my professional development.

$$
\begin{array}{lllll}
1 & 2 & 3 & 4 & 5
\end{array}
$$

College allows me to gain a new perspective on my role in life.

\section{$\begin{array}{lllll}1 & 2 & 3 & 4 & 5\end{array}$}

College helps me learn through direct "hands on" experience.

\section{$\begin{array}{lllll}1 & 2 & 3 & 4 & 5\end{array}$}

I feel the college experience will make a difference when working with coworkers, clients, and the community.

$$
\begin{array}{lllll}
1 & 2 & 3 & 4 & 5
\end{array}
$$

I am able to understand my professional role better through the college experience.

\section{$\begin{array}{lllll}1 & 2 & 3 & 4 & 5\end{array}$}

DAY

Describe any significant activities that occurred today.

How did the experiences today affect you academically and personally?

What did you learn about peers today?

How did your activities today relate to your overall goals? 
Is there anything you would do differently today?

What is your goal(s) for tomorrow?

Rate your overall professional experience today (1) poor to (5) great!

Rate your overall academic experience today from (1) poor to (5) great!

Rate your communication skills today from (1) poor to (5) great! 


\section{SELF-DEVELOPMENT \\ DAILY JOURNAL}

On a scale of $1-5$,

circle the number

that best fits your

thoughts from

strongly disagree (1)

to strongly agree (5)

I am contributing to my professional development.

$$
\begin{array}{lllll}
1 & 2 & 3 & 4 & 5
\end{array}
$$

College allows me to gain a new perspective on my role in life.

\section{$\begin{array}{lllll}1 & 2 & 3 & 4 & 5\end{array}$}

College helps me learn through direct "hands on" experience.

\section{$\begin{array}{lllll}1 & 2 & 3 & 4 & 5\end{array}$}

I feel the college experience will make a difference when working with coworkers, clients, and the community.

$$
\begin{array}{lllll}
1 & 2 & 3 & 4 & 5
\end{array}
$$

I am able to understand my professional role better through the college experience.

\section{$\begin{array}{lllll}1 & 2 & 3 & 4 & 5\end{array}$}

DAY

Describe any significant activities that occurred today.

How did the experiences today affect you academically and personally?

What did you learn about peers today?

How did your activities today relate to your overall goals? 
Is there anything you would do differently today?

What is your goal(s) for tomorrow?

Rate your overall professional experience today (1) poor to (5) great!

Rate your overall academic experience today from (1) poor to (5) great!

Rate your communication skills today from (1) poor to (5) great! 


\section{SELF-DEVELOPMENT \\ DAILY JOURNAL}

On a scale of $1-5$,

circle the number

that best fits your

thoughts from

strongly disagree (1)

to strongly agree (5)

I am contributing to my professional development.

$$
\begin{array}{lllll}
1 & 2 & 3 & 4 & 5
\end{array}
$$

College allows me to gain a new perspective on my role in life.

\section{$\begin{array}{lllll}1 & 2 & 3 & 4 & 5\end{array}$}

College helps me learn through direct "hands on" experience.

\section{$\begin{array}{lllll}1 & 2 & 3 & 4 & 5\end{array}$}

I feel the college experience will make a difference when working with coworkers, clients, and the community.

$$
\begin{array}{lllll}
1 & 2 & 3 & 4 & 5
\end{array}
$$

I am able to understand my professional role better through the college experience.

\section{$\begin{array}{lllll}1 & 2 & 3 & 4 & 5\end{array}$}

DAY

Describe any significant activities that occurred today.

How did the experiences today affect you academically and personally?

What did you learn about peers today?

How did your activities today relate to your overall goals? 
Is there anything you would do differently today?

What is your goal(s) for tomorrow?

Rate your overall professional experience today (1) poor to (5) great!

Rate your overall academic experience today from (1) poor to (5) great!

Rate your communication skills today from (1) poor to (5) great! 


\section{SELF-DEVELOPMENT \\ DAILY JOURNAL}

On a scale of $1-5$,

circle the number

that best fits your

thoughts from

strongly disagree (1)

to strongly agree (5)

I am contributing to my professional development.

$$
\begin{array}{lllll}
1 & 2 & 3 & 4 & 5
\end{array}
$$

College allows me to gain a new perspective on my role in life.

\section{$\begin{array}{lllll}1 & 2 & 3 & 4 & 5\end{array}$}

College helps me learn through direct "hands on" experience.

\section{$\begin{array}{lllll}1 & 2 & 3 & 4 & 5\end{array}$}

I feel the college experience will make a difference when working with coworkers, clients, and the community.

$$
\begin{array}{lllll}
1 & 2 & 3 & 4 & 5
\end{array}
$$

I am able to understand my professional role better through the college experience.

\section{$\begin{array}{lllll}1 & 2 & 3 & 4 & 5\end{array}$}

DAY

Describe any significant activities that occurred today.

How did the experiences today affect you academically and personally?

What did you learn about peers today?

How did your activities today relate to your overall goals? 
Is there anything you would do differently today?

What is your goal(s) for tomorrow?

Rate your overall professional experience today (1) poor to (5) great!

Rate your overall academic experience today from (1) poor to (5) great!

Rate your communication skills today from (1) poor to (5) great! 


\section{SELF-DEVELOPMENT \\ DAILY JOURNAL}

On a scale of $1-5$,

circle the number

that best fits your

thoughts from

strongly disagree (1)

to strongly agree (5)

I am contributing to my professional development.

$$
\begin{array}{lllll}
1 & 2 & 3 & 4 & 5
\end{array}
$$

College allows me to gain a new perspective on my role in life.

\section{$\begin{array}{lllll}1 & 2 & 3 & 4 & 5\end{array}$}

College helps me learn through direct "hands on" experience.

\section{$\begin{array}{lllll}1 & 2 & 3 & 4 & 5\end{array}$}

I feel the college experience will make a difference when working with coworkers, clients, and the community.

$$
\begin{array}{lllll}
1 & 2 & 3 & 4 & 5
\end{array}
$$

I am able to understand my professional role better through the college experience.

\section{$\begin{array}{lllll}1 & 2 & 3 & 4 & 5\end{array}$}

DAY

Describe any significant activities that occurred today.

How did the experiences today affect you academically and personally?

What did you learn about peers today?

How did your activities today relate to your overall goals? 
Is there anything you would do differently today?

What is your goal(s) for tomorrow?

Rate your overall professional experience today (1) poor to (5) great!

Rate your overall academic experience today from (1) poor to (5) great!

Rate your communication skills today from (1) poor to (5) great! 


\section{SELF-DEVELOPMENT \\ DAILY JOURNAL}

On a scale of $1-5$,

circle the number

that best fits your

thoughts from

strongly disagree (1)

to strongly agree (5)

I am contributing to my professional development.

$$
\begin{array}{lllll}
1 & 2 & 3 & 4 & 5
\end{array}
$$

College allows me to gain a new perspective on my role in life.

\section{$\begin{array}{lllll}1 & 2 & 3 & 4 & 5\end{array}$}

College helps me learn through direct "hands on" experience.

\section{$\begin{array}{lllll}1 & 2 & 3 & 4 & 5\end{array}$}

I feel the college experience will make a difference when working with coworkers, clients, and the community.

$$
\begin{array}{lllll}
1 & 2 & 3 & 4 & 5
\end{array}
$$

I am able to understand my professional role better through the college experience.

\section{$\begin{array}{lllll}1 & 2 & 3 & 4 & 5\end{array}$}

DAY

Describe any significant activities that occurred today.

How did the experiences today affect you academically and personally?

What did you learn about peers today?

How did your activities today relate to your overall goals? 
Is there anything you would do differently today?

What is your goal(s) for tomorrow?

Rate your overall professional experience today (1) poor to (5) great!

Rate your overall academic experience today from (1) poor to (5) great!

Rate your communication skills today from (1) poor to (5) great! 


\section{SELF-DEVELOPMENT \\ DAILY JOURNAL}

On a scale of $1-5$,

circle the number

that best fits your

thoughts from

strongly disagree (1)

to strongly agree (5)

I am contributing to my professional development.

$$
\begin{array}{lllll}
1 & 2 & 3 & 4 & 5
\end{array}
$$

College allows me to gain a new perspective on my role in life.

\section{$\begin{array}{lllll}1 & 2 & 3 & 4 & 5\end{array}$}

College helps me learn through direct "hands on" experience.

\section{$\begin{array}{lllll}1 & 2 & 3 & 4 & 5\end{array}$}

I feel the college experience will make a difference when working with coworkers, clients, and the community.

$$
\begin{array}{lllll}
1 & 2 & 3 & 4 & 5
\end{array}
$$

I am able to understand my professional role better through the college experience.

\section{$\begin{array}{lllll}1 & 2 & 3 & 4 & 5\end{array}$}

DAY

Describe any significant activities that occurred today.

How did the experiences today affect you academically and personally?

What did you learn about peers today?

How did your activities today relate to your overall goals? 
Is there anything you would do differently today?

What is your goal(s) for tomorrow?

Rate your overall professional experience today (1) poor to (5) great!

Rate your overall academic experience today from (1) poor to (5) great!

Rate your communication skills today from (1) poor to (5) great! 


\section{SELF-DEVELOPMENT \\ DAILY JOURNAL}

On a scale of $1-5$,

circle the number

that best fits your

thoughts from

strongly disagree (1)

to strongly agree (5)

I am contributing to my professional development.

$$
\begin{array}{lllll}
1 & 2 & 3 & 4 & 5
\end{array}
$$

College allows me to gain a new perspective on my role in life.

\section{$\begin{array}{lllll}1 & 2 & 3 & 4 & 5\end{array}$}

College helps me learn through direct "hands on" experience.

\section{$\begin{array}{lllll}1 & 2 & 3 & 4 & 5\end{array}$}

I feel the college experience will make a difference when working with coworkers, clients, and the community.

$$
\begin{array}{lllll}
1 & 2 & 3 & 4 & 5
\end{array}
$$

I am able to understand my professional role better through the college experience.

\section{$\begin{array}{lllll}1 & 2 & 3 & 4 & 5\end{array}$}

DAY

Describe any significant activities that occurred today.

How did the experiences today affect you academically and personally?

What did you learn about peers today?

How did your activities today relate to your overall goals? 
Is there anything you would do differently today?

What is your goal(s) for tomorrow?

Rate your overall professional experience today (1) poor to (5) great!

Rate your overall academic experience today from (1) poor to (5) great!

Rate your communication skills today from (1) poor to (5) great! 


\section{SELF-DEVELOPMENT \\ DAILY JOURNAL}

On a scale of $1-5$,

circle the number

that best fits your

thoughts from

strongly disagree (1)

to strongly agree (5)

I am contributing to my professional development.

$$
\begin{array}{lllll}
1 & 2 & 3 & 4 & 5
\end{array}
$$

College allows me to gain a new perspective on my role in life.

\section{$\begin{array}{lllll}1 & 2 & 3 & 4 & 5\end{array}$}

College helps me learn through direct "hands on" experience.

\section{$\begin{array}{lllll}1 & 2 & 3 & 4 & 5\end{array}$}

I feel the college experience will make a difference when working with coworkers, clients, and the community.

$$
\begin{array}{lllll}
1 & 2 & 3 & 4 & 5
\end{array}
$$

I am able to understand my professional role better through the college experience.

\section{$\begin{array}{lllll}1 & 2 & 3 & 4 & 5\end{array}$}

DAY

Describe any significant activities that occurred today.

How did the experiences today affect you academically and personally?

What did you learn about peers today?

How did your activities today relate to your overall goals? 
Is there anything you would do differently today?

What is your goal(s) for tomorrow?

Rate your overall professional experience today (1) poor to (5) great!

Rate your overall academic experience today from (1) poor to (5) great!

Rate your communication skills today from (1) poor to (5) great! 


\section{SELF-DEVELOPMENT \\ DAILY JOURNAL}

On a scale of $1-5$,

circle the number

that best fits your

thoughts from

strongly disagree (1)

to strongly agree (5)

I am contributing to my professional development.

$$
\begin{array}{lllll}
1 & 2 & 3 & 4 & 5
\end{array}
$$

College allows me to gain a new perspective on my role in life.

\section{$\begin{array}{lllll}1 & 2 & 3 & 4 & 5\end{array}$}

College helps me learn through direct "hands on" experience.

\section{$\begin{array}{lllll}1 & 2 & 3 & 4 & 5\end{array}$}

I feel the college experience will make a difference when working with coworkers, clients, and the community.

$$
\begin{array}{lllll}
1 & 2 & 3 & 4 & 5
\end{array}
$$

I am able to understand my professional role better through the college experience.

\section{$\begin{array}{lllll}1 & 2 & 3 & 4 & 5\end{array}$}

DAY

Describe any significant activities that occurred today.

How did the experiences today affect you academically and personally?

What did you learn about peers today?

How did your activities today relate to your overall goals? 
Is there anything you would do differently today?

What is your goal(s) for tomorrow?

Rate your overall professional experience today (1) poor to (5) great!

Rate your overall academic experience today from (1) poor to (5) great!

Rate your communication skills today from (1) poor to (5) great! 


\section{SELF-DEVELOPMENT \\ DAILY JOURNAL}

On a scale of $1-5$,

circle the number

that best fits your

thoughts from

strongly disagree (1)

to strongly agree (5)

I am contributing to my professional development.

$$
\begin{array}{lllll}
1 & 2 & 3 & 4 & 5
\end{array}
$$

College allows me to gain a new perspective on my role in life.

\section{$\begin{array}{lllll}1 & 2 & 3 & 4 & 5\end{array}$}

College helps me learn through direct "hands on" experience.

\section{$\begin{array}{lllll}1 & 2 & 3 & 4 & 5\end{array}$}

I feel the college experience will make a difference when working with coworkers, clients, and the community.

$$
\begin{array}{lllll}
1 & 2 & 3 & 4 & 5
\end{array}
$$

I am able to understand my professional role better through the college experience.

\section{$\begin{array}{lllll}1 & 2 & 3 & 4 & 5\end{array}$}

DAY

Describe any significant activities that occurred today.

How did the experiences today affect you academically and personally?

What did you learn about peers today?

How did your activities today relate to your overall goals? 
Is there anything you would do differently today?

What is your goal(s) for tomorrow?

Rate your overall professional experience today (1) poor to (5) great!

Rate your overall academic experience today from (1) poor to (5) great!

Rate your communication skills today from (1) poor to (5) great! 


\section{SELF-DEVELOPMENT \\ DAILY JOURNAL}

On a scale of $1-5$,

circle the number

that best fits your

thoughts from

strongly disagree (1)

to strongly agree (5)

I am contributing to my professional development.

$$
\begin{array}{lllll}
1 & 2 & 3 & 4 & 5
\end{array}
$$

College allows me to gain a new perspective on my role in life.

\section{$\begin{array}{lllll}1 & 2 & 3 & 4 & 5\end{array}$}

College helps me learn through direct "hands on" experience.

\section{$\begin{array}{lllll}1 & 2 & 3 & 4 & 5\end{array}$}

I feel the college experience will make a difference when working with coworkers, clients, and the community.

$$
\begin{array}{lllll}
1 & 2 & 3 & 4 & 5
\end{array}
$$

I am able to understand my professional role better through the college experience.

\section{$\begin{array}{lllll}1 & 2 & 3 & 4 & 5\end{array}$}

DAY

Describe any significant activities that occurred today.

How did the experiences today affect you academically and personally?

What did you learn about peers today?

How did your activities today relate to your overall goals? 
Is there anything you would do differently today?

What is your goal(s) for tomorrow?

Rate your overall professional experience today (1) poor to (5) great!

Rate your overall academic experience today from (1) poor to (5) great!

Rate your communication skills today from (1) poor to (5) great! 


\section{SELF-DEVELOPMENT \\ DAILY JOURNAL}

On a scale of $1-5$,

circle the number

that best fits your

thoughts from

strongly disagree (1)

to strongly agree (5)

I am contributing to my professional development.

$$
\begin{array}{lllll}
1 & 2 & 3 & 4 & 5
\end{array}
$$

College allows me to gain a new perspective on my role in life.

\section{$\begin{array}{lllll}1 & 2 & 3 & 4 & 5\end{array}$}

College helps me learn through direct "hands on" experience.

\section{$\begin{array}{lllll}1 & 2 & 3 & 4 & 5\end{array}$}

I feel the college experience will make a difference when working with coworkers, clients, and the community.

$$
\begin{array}{lllll}
1 & 2 & 3 & 4 & 5
\end{array}
$$

I am able to understand my professional role better through the college experience.

\section{$\begin{array}{lllll}1 & 2 & 3 & 4 & 5\end{array}$}

DAY

Describe any significant activities that occurred today.

How did the experiences today affect you academically and personally?

What did you learn about peers today?

How did your activities today relate to your overall goals? 
Is there anything you would do differently today?

What is your goal(s) for tomorrow?

Rate your overall professional experience today (1) poor to (5) great!

Rate your overall academic experience today from (1) poor to (5) great!

Rate your communication skills today from (1) poor to (5) great! 


\section{SELF-DEVELOPMENT \\ DAILY JOURNAL}

On a scale of $1-5$,

circle the number

that best fits your

thoughts from

strongly disagree (1)

to strongly agree (5)

I am contributing to my professional development.

$$
\begin{array}{lllll}
1 & 2 & 3 & 4 & 5
\end{array}
$$

College allows me to gain a new perspective on my role in life.

\section{$\begin{array}{lllll}1 & 2 & 3 & 4 & 5\end{array}$}

College helps me learn through direct "hands on" experience.

\section{$\begin{array}{lllll}1 & 2 & 3 & 4 & 5\end{array}$}

I feel the college experience will make a difference when working with coworkers, clients, and the community.

$$
\begin{array}{lllll}
1 & 2 & 3 & 4 & 5
\end{array}
$$

I am able to understand my professional role better through the college experience.

\section{$\begin{array}{lllll}1 & 2 & 3 & 4 & 5\end{array}$}

DAY

Describe any significant activities that occurred today.

How did the experiences today affect you academically and personally?

What did you learn about peers today?

How did your activities today relate to your overall goals? 
Is there anything you would do differently today?

What is your goal(s) for tomorrow?

Rate your overall professional experience today (1) poor to (5) great!

Rate your overall academic experience today from (1) poor to (5) great!

Rate your communication skills today from (1) poor to (5) great! 


\section{SELF-DEVELOPMENT \\ DAILY JOURNAL}

On a scale of $1-5$,

circle the number

that best fits your

thoughts from

strongly disagree (1)

to strongly agree (5)

I am contributing to my professional development.

$$
\begin{array}{lllll}
1 & 2 & 3 & 4 & 5
\end{array}
$$

College allows me to gain a new perspective on my role in life.

\section{$\begin{array}{lllll}1 & 2 & 3 & 4 & 5\end{array}$}

College helps me learn through direct "hands on" experience.

\section{$\begin{array}{lllll}1 & 2 & 3 & 4 & 5\end{array}$}

I feel the college experience will make a difference when working with coworkers, clients, and the community.

$$
\begin{array}{lllll}
1 & 2 & 3 & 4 & 5
\end{array}
$$

I am able to understand my professional role better through the college experience.

\section{$\begin{array}{lllll}1 & 2 & 3 & 4 & 5\end{array}$}

DAY

Describe any significant activities that occurred today.

How did the experiences today affect you academically and personally?

What did you learn about peers today?

How did your activities today relate to your overall goals? 
Is there anything you would do differently today?

What is your goal(s) for tomorrow?

Rate your overall professional experience today (1) poor to (5) great!

Rate your overall academic experience today from (1) poor to (5) great!

Rate your communication skills today from (1) poor to (5) great! 


\section{SELF-DEVELOPMENT \\ DAILY JOURNAL}

On a scale of $1-5$,

circle the number

that best fits your

thoughts from

strongly disagree (1)

to strongly agree (5)

I am contributing to my professional development.

$$
\begin{array}{lllll}
1 & 2 & 3 & 4 & 5
\end{array}
$$

College allows me to gain a new perspective on my role in life.

\section{$\begin{array}{lllll}1 & 2 & 3 & 4 & 5\end{array}$}

College helps me learn through direct "hands on" experience.

\section{$\begin{array}{lllll}1 & 2 & 3 & 4 & 5\end{array}$}

I feel the college experience will make a difference when working with coworkers, clients, and the community.

$$
\begin{array}{lllll}
1 & 2 & 3 & 4 & 5
\end{array}
$$

I am able to understand my professional role better through the college experience.

\section{$\begin{array}{lllll}1 & 2 & 3 & 4 & 5\end{array}$}

DAY

Describe any significant activities that occurred today.

How did the experiences today affect you academically and personally?

What did you learn about peers today?

How did your activities today relate to your overall goals? 
Is there anything you would do differently today?

What is your goal(s) for tomorrow?

Rate your overall professional experience today (1) poor to (5) great!

Rate your overall academic experience today from (1) poor to (5) great!

Rate your communication skills today from (1) poor to (5) great! 


\section{SELF-DEVELOPMENT \\ DAILY JOURNAL}

On a scale of $1-5$,

circle the number

that best fits your

thoughts from

strongly disagree (1)

to strongly agree (5)

I am contributing to my professional development.

$$
\begin{array}{lllll}
1 & 2 & 3 & 4 & 5
\end{array}
$$

College allows me to gain a new perspective on my role in life.

\section{$\begin{array}{lllll}1 & 2 & 3 & 4 & 5\end{array}$}

College helps me learn through direct "hands on" experience.

\section{$\begin{array}{lllll}1 & 2 & 3 & 4 & 5\end{array}$}

I feel the college experience will make a difference when working with coworkers, clients, and the community.

$$
\begin{array}{lllll}
1 & 2 & 3 & 4 & 5
\end{array}
$$

I am able to understand my professional role better through the college experience.

\section{$\begin{array}{lllll}1 & 2 & 3 & 4 & 5\end{array}$}

DAY

Describe any significant activities that occurred today.

How did the experiences today affect you academically and personally?

What did you learn about peers today?

How did your activities today relate to your overall goals? 
Is there anything you would do differently today?

What is your goal(s) for tomorrow?

Rate your overall professional experience today (1) poor to (5) great!

Rate your overall academic experience today from (1) poor to (5) great!

Rate your communication skills today from (1) poor to (5) great! 


\section{SELF-DEVELOPMENT \\ DAILY JOURNAL}

On a scale of $1-5$,

circle the number

that best fits your

thoughts from

strongly disagree (1)

to strongly agree (5)

I am contributing to my professional development.

$$
\begin{array}{lllll}
1 & 2 & 3 & 4 & 5
\end{array}
$$

College allows me to gain a new perspective on my role in life.

\section{$\begin{array}{lllll}1 & 2 & 3 & 4 & 5\end{array}$}

College helps me learn through direct "hands on" experience.

\section{$\begin{array}{lllll}1 & 2 & 3 & 4 & 5\end{array}$}

I feel the college experience will make a difference when working with coworkers, clients, and the community.

$$
\begin{array}{lllll}
1 & 2 & 3 & 4 & 5
\end{array}
$$

I am able to understand my professional role better through the college experience.

\section{$\begin{array}{lllll}1 & 2 & 3 & 4 & 5\end{array}$}

DAY

Describe any significant activities that occurred today.

How did the experiences today affect you academically and personally?

What did you learn about peers today?

How did your activities today relate to your overall goals? 
Is there anything you would do differently today?

What is your goal(s) for tomorrow?

Rate your overall professional experience today (1) poor to (5) great!

Rate your overall academic experience today from (1) poor to (5) great!

Rate your communication skills today from (1) poor to (5) great! 


\section{SELF-DEVELOPMENT \\ DAILY JOURNAL}

On a scale of $1-5$,

circle the number

that best fits your

thoughts from

strongly disagree (1)

to strongly agree (5)

I am contributing to my professional development.

$$
\begin{array}{lllll}
1 & 2 & 3 & 4 & 5
\end{array}
$$

College allows me to gain a new perspective on my role in life.

\section{$\begin{array}{lllll}1 & 2 & 3 & 4 & 5\end{array}$}

College helps me learn through direct "hands on" experience.

\section{$\begin{array}{lllll}1 & 2 & 3 & 4 & 5\end{array}$}

I feel the college experience will make a difference when working with coworkers, clients, and the community.

$$
\begin{array}{lllll}
1 & 2 & 3 & 4 & 5
\end{array}
$$

I am able to understand my professional role better through the college experience.

\section{$\begin{array}{lllll}1 & 2 & 3 & 4 & 5\end{array}$}

DAY

Describe any significant activities that occurred today.

How did the experiences today affect you academically and personally?

What did you learn about peers today?

How did your activities today relate to your overall goals? 
Is there anything you would do differently today?

What is your goal(s) for tomorrow?

Rate your overall professional experience today (1) poor to (5) great!

Rate your overall academic experience today from (1) poor to (5) great!

Rate your communication skills today from (1) poor to (5) great! 


\section{SELF-DEVELOPMENT \\ DAILY JOURNAL}

On a scale of $1-5$,

circle the number

that best fits your

thoughts from

strongly disagree (1)

to strongly agree (5)

I am contributing to my professional development.

$$
\begin{array}{lllll}
1 & 2 & 3 & 4 & 5
\end{array}
$$

College allows me to gain a new perspective on my role in life.

\section{$\begin{array}{lllll}1 & 2 & 3 & 4 & 5\end{array}$}

College helps me learn through direct "hands on" experience.

\section{$\begin{array}{lllll}1 & 2 & 3 & 4 & 5\end{array}$}

I feel the college experience will make a difference when working with coworkers, clients, and the community.

$$
\begin{array}{lllll}
1 & 2 & 3 & 4 & 5
\end{array}
$$

I am able to understand my professional role better through the college experience.

\section{$\begin{array}{lllll}1 & 2 & 3 & 4 & 5\end{array}$}

DAY

Describe any significant activities that occurred today.

How did the experiences today affect you academically and personally?

What did you learn about peers today?

How did your activities today relate to your overall goals? 
Is there anything you would do differently today?

What is your goal(s) for tomorrow?

Rate your overall professional experience today (1) poor to (5) great!

Rate your overall academic experience today from (1) poor to (5) great!

Rate your communication skills today from (1) poor to (5) great! 


\section{SELF-DEVELOPMENT \\ DAILY JOURNAL}

On a scale of $1-5$,

circle the number

that best fits your

thoughts from

strongly disagree (1)

to strongly agree (5)

I am contributing to my professional development.

$$
\begin{array}{lllll}
1 & 2 & 3 & 4 & 5
\end{array}
$$

College allows me to gain a new perspective on my role in life.

\section{$\begin{array}{lllll}1 & 2 & 3 & 4 & 5\end{array}$}

College helps me learn through direct "hands on" experience.

\section{$\begin{array}{lllll}1 & 2 & 3 & 4 & 5\end{array}$}

I feel the college experience will make a difference when working with coworkers, clients, and the community.

$$
\begin{array}{lllll}
1 & 2 & 3 & 4 & 5
\end{array}
$$

I am able to understand my professional role better through the college experience.

\section{$\begin{array}{lllll}1 & 2 & 3 & 4 & 5\end{array}$}

DAY

Describe any significant activities that occurred today.

How did the experiences today affect you academically and personally?

What did you learn about peers today?

How did your activities today relate to your overall goals? 
Is there anything you would do differently today?

What is your goal(s) for tomorrow?

Rate your overall professional experience today (1) poor to (5) great!

Rate your overall academic experience today from (1) poor to (5) great!

Rate your communication skills today from (1) poor to (5) great! 


\section{SELF-DEVELOPMENT \\ DAILY JOURNAL}

On a scale of $1-5$,

circle the number

that best fits your

thoughts from

strongly disagree (1)

to strongly agree (5)

I am contributing to my professional development.

$$
\begin{array}{lllll}
1 & 2 & 3 & 4 & 5
\end{array}
$$

College allows me to gain a new perspective on my role in life.

\section{$\begin{array}{lllll}1 & 2 & 3 & 4 & 5\end{array}$}

College helps me learn through direct "hands on" experience.

\section{$\begin{array}{lllll}1 & 2 & 3 & 4 & 5\end{array}$}

I feel the college experience will make a difference when working with coworkers, clients, and the community.

$$
\begin{array}{lllll}
1 & 2 & 3 & 4 & 5
\end{array}
$$

I am able to understand my professional role better through the college experience.

\section{$\begin{array}{lllll}1 & 2 & 3 & 4 & 5\end{array}$}

DAY

Describe any significant activities that occurred today.

How did the experiences today affect you academically and personally?

What did you learn about peers today?

How did your activities today relate to your overall goals? 
Is there anything you would do differently today?

What is your goal(s) for tomorrow?

Rate your overall professional experience today (1) poor to (5) great!

Rate your overall academic experience today from (1) poor to (5) great!

Rate your communication skills today from (1) poor to (5) great! 


\section{SELF-DEVELOPMENT \\ DAILY JOURNAL}

On a scale of $1-5$,

circle the number

that best fits your

thoughts from

strongly disagree (1)

to strongly agree (5)

I am contributing to my professional development.

$$
\begin{array}{lllll}
1 & 2 & 3 & 4 & 5
\end{array}
$$

College allows me to gain a new perspective on my role in life.

\section{$\begin{array}{lllll}1 & 2 & 3 & 4 & 5\end{array}$}

College helps me learn through direct "hands on" experience.

\section{$\begin{array}{lllll}1 & 2 & 3 & 4 & 5\end{array}$}

I feel the college experience will make a difference when working with coworkers, clients, and the community.

$$
\begin{array}{lllll}
1 & 2 & 3 & 4 & 5
\end{array}
$$

I am able to understand my professional role better through the college experience.

\section{$\begin{array}{lllll}1 & 2 & 3 & 4 & 5\end{array}$}

DAY

Describe any significant activities that occurred today.

How did the experiences today affect you academically and personally?

What did you learn about peers today?

How did your activities today relate to your overall goals? 
Is there anything you would do differently today?

What is your goal(s) for tomorrow?

Rate your overall professional experience today (1) poor to (5) great!

Rate your overall academic experience today from (1) poor to (5) great!

Rate your communication skills today from (1) poor to (5) great! 


\section{SELF-DEVELOPMENT \\ DAILY JOURNAL}

On a scale of $1-5$,

circle the number

that best fits your

thoughts from

strongly disagree (1)

to strongly agree (5)

I am contributing to my professional development.

$$
\begin{array}{lllll}
1 & 2 & 3 & 4 & 5
\end{array}
$$

College allows me to gain a new perspective on my role in life.

\section{$\begin{array}{lllll}1 & 2 & 3 & 4 & 5\end{array}$}

College helps me learn through direct "hands on" experience.

\section{$\begin{array}{lllll}1 & 2 & 3 & 4 & 5\end{array}$}

I feel the college experience will make a difference when working with coworkers, clients, and the community.

$$
\begin{array}{lllll}
1 & 2 & 3 & 4 & 5
\end{array}
$$

I am able to understand my professional role better through the college experience.

\section{$\begin{array}{lllll}1 & 2 & 3 & 4 & 5\end{array}$}

DAY

Describe any significant activities that occurred today.

How did the experiences today affect you academically and personally?

What did you learn about peers today?

How did your activities today relate to your overall goals? 
Is there anything you would do differently today?

What is your goal(s) for tomorrow?

Rate your overall professional experience today (1) poor to (5) great!

Rate your overall academic experience today from (1) poor to (5) great!

Rate your communication skills today from (1) poor to (5) great! 


\section{SELF-DEVELOPMENT \\ DAILY JOURNAL}

On a scale of $1-5$,

circle the number

that best fits your

thoughts from

strongly disagree (1)

to strongly agree (5)

I am contributing to my professional development.

$$
\begin{array}{lllll}
1 & 2 & 3 & 4 & 5
\end{array}
$$

College allows me to gain a new perspective on my role in life.

\section{$\begin{array}{lllll}1 & 2 & 3 & 4 & 5\end{array}$}

College helps me learn through direct "hands on" experience.

\section{$\begin{array}{lllll}1 & 2 & 3 & 4 & 5\end{array}$}

I feel the college experience will make a difference when working with coworkers, clients, and the community.

$$
\begin{array}{lllll}
1 & 2 & 3 & 4 & 5
\end{array}
$$

I am able to understand my professional role better through the college experience.

\section{$\begin{array}{lllll}1 & 2 & 3 & 4 & 5\end{array}$}

DAY

Describe any significant activities that occurred today.

How did the experiences today affect you academically and personally?

What did you learn about peers today?

How did your activities today relate to your overall goals? 
Is there anything you would do differently today?

What is your goal(s) for tomorrow?

Rate your overall professional experience today (1) poor to (5) great!

Rate your overall academic experience today from (1) poor to (5) great!

Rate your communication skills today from (1) poor to (5) great! 


\section{SELF-DEVELOPMENT \\ DAILY JOURNAL}

On a scale of $1-5$,

circle the number

that best fits your

thoughts from

strongly disagree (1)

to strongly agree (5)

I am contributing to my professional development.

$$
\begin{array}{lllll}
1 & 2 & 3 & 4 & 5
\end{array}
$$

College allows me to gain a new perspective on my role in life.

\section{$\begin{array}{lllll}1 & 2 & 3 & 4 & 5\end{array}$}

College helps me learn through direct "hands on" experience.

\section{$\begin{array}{lllll}1 & 2 & 3 & 4 & 5\end{array}$}

I feel the college experience will make a difference when working with coworkers, clients, and the community.

$$
\begin{array}{lllll}
1 & 2 & 3 & 4 & 5
\end{array}
$$

I am able to understand my professional role better through the college experience.

\section{$\begin{array}{lllll}1 & 2 & 3 & 4 & 5\end{array}$}

DAY

Describe any significant activities that occurred today.

How did the experiences today affect you academically and personally?

What did you learn about peers today?

How did your activities today relate to your overall goals? 
Is there anything you would do differently today?

What is your goal(s) for tomorrow?

Rate your overall professional experience today (1) poor to (5) great!

Rate your overall academic experience today from (1) poor to (5) great!

Rate your communication skills today from (1) poor to (5) great! 


\section{SELF-DEVELOPMENT \\ DAILY JOURNAL}

On a scale of $1-5$,

circle the number

that best fits your

thoughts from

strongly disagree (1)

to strongly agree (5)

I am contributing to my professional development.

$$
\begin{array}{lllll}
1 & 2 & 3 & 4 & 5
\end{array}
$$

College allows me to gain a new perspective on my role in life.

\section{$\begin{array}{lllll}1 & 2 & 3 & 4 & 5\end{array}$}

College helps me learn through direct "hands on" experience.

\section{$\begin{array}{lllll}1 & 2 & 3 & 4 & 5\end{array}$}

I feel the college experience will make a difference when working with coworkers, clients, and the community.

$$
\begin{array}{lllll}
1 & 2 & 3 & 4 & 5
\end{array}
$$

I am able to understand my professional role better through the college experience.

\section{$\begin{array}{lllll}1 & 2 & 3 & 4 & 5\end{array}$}

DAY

Describe any significant activities that occurred today.

How did the experiences today affect you academically and personally?

What did you learn about peers today?

How did your activities today relate to your overall goals? 
Is there anything you would do differently today?

What is your goal(s) for tomorrow?

Rate your overall professional experience today (1) poor to (5) great!

Rate your overall academic experience today from (1) poor to (5) great!

Rate your communication skills today from (1) poor to (5) great! 


\section{SELF-DEVELOPMENT \\ DAILY JOURNAL}

On a scale of $1-5$,

circle the number

that best fits your

thoughts from

strongly disagree (1)

to strongly agree (5)

I am contributing to my professional development.

$$
\begin{array}{lllll}
1 & 2 & 3 & 4 & 5
\end{array}
$$

College allows me to gain a new perspective on my role in life.

\section{$\begin{array}{lllll}1 & 2 & 3 & 4 & 5\end{array}$}

College helps me learn through direct "hands on" experience.

\section{$\begin{array}{lllll}1 & 2 & 3 & 4 & 5\end{array}$}

I feel the college experience will make a difference when working with coworkers, clients, and the community.

$$
\begin{array}{lllll}
1 & 2 & 3 & 4 & 5
\end{array}
$$

I am able to understand my professional role better through the college experience.

\section{$\begin{array}{lllll}1 & 2 & 3 & 4 & 5\end{array}$}

DAY

Describe any significant activities that occurred today.

How did the experiences today affect you academically and personally?

What did you learn about peers today?

How did your activities today relate to your overall goals? 
Is there anything you would do differently today?

What is your goal(s) for tomorrow?

Rate your overall professional experience today (1) poor to (5) great!

Rate your overall academic experience today from (1) poor to (5) great!

Rate your communication skills today from (1) poor to (5) great! 


\section{SELF-DEVELOPMENT \\ DAILY JOURNAL}

On a scale of $1-5$,

circle the number

that best fits your

thoughts from

strongly disagree (1)

to strongly agree (5)

I am contributing to my professional development.

$$
\begin{array}{lllll}
1 & 2 & 3 & 4 & 5
\end{array}
$$

College allows me to gain a new perspective on my role in life.

\section{$\begin{array}{lllll}1 & 2 & 3 & 4 & 5\end{array}$}

College helps me learn through direct "hands on" experience.

\section{$\begin{array}{lllll}1 & 2 & 3 & 4 & 5\end{array}$}

I feel the college experience will make a difference when working with coworkers, clients, and the community.

$$
\begin{array}{lllll}
1 & 2 & 3 & 4 & 5
\end{array}
$$

I am able to understand my professional role better through the college experience.

\section{$\begin{array}{lllll}1 & 2 & 3 & 4 & 5\end{array}$}

DAY

Describe any significant activities that occurred today.

How did the experiences today affect you academically and personally?

What did you learn about peers today?

How did your activities today relate to your overall goals? 
Is there anything you would do differently today?

What is your goal(s) for tomorrow?

Rate your overall professional experience today (1) poor to (5) great!

Rate your overall academic experience today from (1) poor to (5) great!

Rate your communication skills today from (1) poor to (5) great! 


\section{SELF-DEVELOPMENT \\ DAILY JOURNAL}

On a scale of $1-5$,

circle the number

that best fits your

thoughts from

strongly disagree (1)

to strongly agree (5)

I am contributing to my professional development.

$$
\begin{array}{lllll}
1 & 2 & 3 & 4 & 5
\end{array}
$$

College allows me to gain a new perspective on my role in life.

\section{$\begin{array}{lllll}1 & 2 & 3 & 4 & 5\end{array}$}

College helps me learn through direct "hands on" experience.

\section{$\begin{array}{lllll}1 & 2 & 3 & 4 & 5\end{array}$}

I feel the college experience will make a difference when working with coworkers, clients, and the community.

$$
\begin{array}{lllll}
1 & 2 & 3 & 4 & 5
\end{array}
$$

I am able to understand my professional role better through the college experience.

\section{$\begin{array}{lllll}1 & 2 & 3 & 4 & 5\end{array}$}

DAY

Describe any significant activities that occurred today.

How did the experiences today affect you academically and personally?

What did you learn about peers today?

How did your activities today relate to your overall goals? 
Is there anything you would do differently today?

What is your goal(s) for tomorrow?

Rate your overall professional experience today (1) poor to (5) great!

Rate your overall academic experience today from (1) poor to (5) great!

Rate your communication skills today from (1) poor to (5) great! 


\section{SELF-DEVELOPMENT \\ DAILY JOURNAL}

On a scale of $1-5$,

circle the number

that best fits your

thoughts from

strongly disagree (1)

to strongly agree (5)

I am contributing to my professional development.

$$
\begin{array}{lllll}
1 & 2 & 3 & 4 & 5
\end{array}
$$

College allows me to gain a new perspective on my role in life.

\section{$\begin{array}{lllll}1 & 2 & 3 & 4 & 5\end{array}$}

College helps me learn through direct "hands on" experience.

\section{$\begin{array}{lllll}1 & 2 & 3 & 4 & 5\end{array}$}

I feel the college experience will make a difference when working with coworkers, clients, and the community.

$$
\begin{array}{lllll}
1 & 2 & 3 & 4 & 5
\end{array}
$$

I am able to understand my professional role better through the college experience.

\section{$\begin{array}{lllll}1 & 2 & 3 & 4 & 5\end{array}$}

DAY

Describe any significant activities that occurred today.

How did the experiences today affect you academically and personally?

What did you learn about peers today?

How did your activities today relate to your overall goals? 
Is there anything you would do differently today?

What is your goal(s) for tomorrow?

Rate your overall professional experience today (1) poor to (5) great!

Rate your overall academic experience today from (1) poor to (5) great!

Rate your communication skills today from (1) poor to (5) great! 


\section{SELF-DEVELOPMENT \\ DAILY JOURNAL}

On a scale of $1-5$,

circle the number

that best fits your

thoughts from

strongly disagree (1)

to strongly agree (5)

I am contributing to my professional development.

$$
\begin{array}{lllll}
1 & 2 & 3 & 4 & 5
\end{array}
$$

College allows me to gain a new perspective on my role in life.

\section{$\begin{array}{lllll}1 & 2 & 3 & 4 & 5\end{array}$}

College helps me learn through direct "hands on" experience.

\section{$\begin{array}{lllll}1 & 2 & 3 & 4 & 5\end{array}$}

I feel the college experience will make a difference when working with coworkers, clients, and the community.

$$
\begin{array}{lllll}
1 & 2 & 3 & 4 & 5
\end{array}
$$

I am able to understand my professional role better through the college experience.

\section{$\begin{array}{lllll}1 & 2 & 3 & 4 & 5\end{array}$}

DAY

Describe any significant activities that occurred today.

How did the experiences today affect you academically and personally?

What did you learn about peers today?

How did your activities today relate to your overall goals? 
Is there anything you would do differently today?

What is your goal(s) for tomorrow?

Rate your overall professional experience today (1) poor to (5) great!

Rate your overall academic experience today from (1) poor to (5) great!

Rate your communication skills today from (1) poor to (5) great! 


\section{SELF-DEVELOPMENT \\ DAILY JOURNAL}

On a scale of $1-5$,

circle the number

that best fits your

thoughts from

strongly disagree (1)

to strongly agree (5)

I am contributing to my professional development.

$$
\begin{array}{lllll}
1 & 2 & 3 & 4 & 5
\end{array}
$$

College allows me to gain a new perspective on my role in life.

\section{$\begin{array}{lllll}1 & 2 & 3 & 4 & 5\end{array}$}

College helps me learn through direct "hands on" experience.

\section{$\begin{array}{lllll}1 & 2 & 3 & 4 & 5\end{array}$}

I feel the college experience will make a difference when working with coworkers, clients, and the community.

$$
\begin{array}{lllll}
1 & 2 & 3 & 4 & 5
\end{array}
$$

I am able to understand my professional role better through the college experience.

\section{$\begin{array}{lllll}1 & 2 & 3 & 4 & 5\end{array}$}

DAY

Describe any significant activities that occurred today.

How did the experiences today affect you academically and personally?

What did you learn about peers today?

How did your activities today relate to your overall goals? 
Is there anything you would do differently today?

What is your goal(s) for tomorrow?

Rate your overall professional experience today (1) poor to (5) great!

Rate your overall academic experience today from (1) poor to (5) great!

Rate your communication skills today from (1) poor to (5) great! 


\section{SELF-DEVELOPMENT \\ DAILY JOURNAL}

On a scale of $1-5$,

circle the number

that best fits your

thoughts from

strongly disagree (1)

to strongly agree (5)

I am contributing to my professional development.

$$
\begin{array}{lllll}
1 & 2 & 3 & 4 & 5
\end{array}
$$

College allows me to gain a new perspective on my role in life.

\section{$\begin{array}{lllll}1 & 2 & 3 & 4 & 5\end{array}$}

College helps me learn through direct "hands on" experience.

\section{$\begin{array}{lllll}1 & 2 & 3 & 4 & 5\end{array}$}

I feel the college experience will make a difference when working with coworkers, clients, and the community.

$$
\begin{array}{lllll}
1 & 2 & 3 & 4 & 5
\end{array}
$$

I am able to understand my professional role better through the college experience.

\section{$\begin{array}{lllll}1 & 2 & 3 & 4 & 5\end{array}$}

DAY

Describe any significant activities that occurred today.

How did the experiences today affect you academically and personally?

What did you learn about peers today?

How did your activities today relate to your overall goals? 
Is there anything you would do differently today?

What is your goal(s) for tomorrow?

Rate your overall professional experience today (1) poor to (5) great!

Rate your overall academic experience today from (1) poor to (5) great!

Rate your communication skills today from (1) poor to (5) great! 


\section{SELF-DEVELOPMENT \\ DAILY JOURNAL}

On a scale of $1-5$,

circle the number

that best fits your

thoughts from

strongly disagree (1)

to strongly agree (5)

I am contributing to my professional development.

$$
\begin{array}{lllll}
1 & 2 & 3 & 4 & 5
\end{array}
$$

College allows me to gain a new perspective on my role in life.

\section{$\begin{array}{lllll}1 & 2 & 3 & 4 & 5\end{array}$}

College helps me learn through direct "hands on" experience.

\section{$\begin{array}{lllll}1 & 2 & 3 & 4 & 5\end{array}$}

I feel the college experience will make a difference when working with coworkers, clients, and the community.

$$
\begin{array}{lllll}
1 & 2 & 3 & 4 & 5
\end{array}
$$

I am able to understand my professional role better through the college experience.

\section{$\begin{array}{lllll}1 & 2 & 3 & 4 & 5\end{array}$}

DAY

Describe any significant activities that occurred today.

How did the experiences today affect you academically and personally?

What did you learn about peers today?

How did your activities today relate to your overall goals? 
Is there anything you would do differently today?

What is your goal(s) for tomorrow?

Rate your overall professional experience today (1) poor to (5) great!

Rate your overall academic experience today from (1) poor to (5) great!

Rate your communication skills today from (1) poor to (5) great! 


\section{SELF-DEVELOPMENT \\ DAILY JOURNAL}

On a scale of $1-5$,

circle the number

that best fits your

thoughts from

strongly disagree (1)

to strongly agree (5)

I am contributing to my professional development.

$$
\begin{array}{lllll}
1 & 2 & 3 & 4 & 5
\end{array}
$$

College allows me to gain a new perspective on my role in life.

\section{$\begin{array}{lllll}1 & 2 & 3 & 4 & 5\end{array}$}

College helps me learn through direct "hands on" experience.

\section{$\begin{array}{lllll}1 & 2 & 3 & 4 & 5\end{array}$}

I feel the college experience will make a difference when working with coworkers, clients, and the community.

$$
\begin{array}{lllll}
1 & 2 & 3 & 4 & 5
\end{array}
$$

I am able to understand my professional role better through the college experience.

\section{$\begin{array}{lllll}1 & 2 & 3 & 4 & 5\end{array}$}

DAY

Describe any significant activities that occurred today.

How did the experiences today affect you academically and personally?

What did you learn about peers today?

How did your activities today relate to your overall goals? 
Is there anything you would do differently today?

What is your goal(s) for tomorrow?

Rate your overall professional experience today (1) poor to (5) great!

Rate your overall academic experience today from (1) poor to (5) great!

Rate your communication skills today from (1) poor to (5) great! 


\section{SELF-DEVELOPMENT \\ DAILY JOURNAL}

On a scale of $1-5$,

circle the number

that best fits your

thoughts from

strongly disagree (1)

to strongly agree (5)

I am contributing to my professional development.

$$
\begin{array}{lllll}
1 & 2 & 3 & 4 & 5
\end{array}
$$

College allows me to gain a new perspective on my role in life.

\section{$\begin{array}{lllll}1 & 2 & 3 & 4 & 5\end{array}$}

College helps me learn through direct "hands on" experience.

\section{$\begin{array}{lllll}1 & 2 & 3 & 4 & 5\end{array}$}

I feel the college experience will make a difference when working with coworkers, clients, and the community.

$$
\begin{array}{lllll}
1 & 2 & 3 & 4 & 5
\end{array}
$$

I am able to understand my professional role better through the college experience.

\section{$\begin{array}{lllll}1 & 2 & 3 & 4 & 5\end{array}$}

DAY

Describe any significant activities that occurred today.

How did the experiences today affect you academically and personally?

What did you learn about peers today?

How did your activities today relate to your overall goals? 
Is there anything you would do differently today?

What is your goal(s) for tomorrow?

Rate your overall professional experience today (1) poor to (5) great!

Rate your overall academic experience today from (1) poor to (5) great!

Rate your communication skills today from (1) poor to (5) great! 


\section{SELF-DEVELOPMENT \\ DAILY JOURNAL}

On a scale of $1-5$,

circle the number

that best fits your

thoughts from

strongly disagree (1)

to strongly agree (5)

I am contributing to my professional development.

$$
\begin{array}{lllll}
1 & 2 & 3 & 4 & 5
\end{array}
$$

College allows me to gain a new perspective on my role in life.

\section{$\begin{array}{lllll}1 & 2 & 3 & 4 & 5\end{array}$}

College helps me learn through direct "hands on" experience.

\section{$\begin{array}{lllll}1 & 2 & 3 & 4 & 5\end{array}$}

I feel the college experience will make a difference when working with coworkers, clients, and the community.

$$
\begin{array}{lllll}
1 & 2 & 3 & 4 & 5
\end{array}
$$

I am able to understand my professional role better through the college experience.

\section{$\begin{array}{lllll}1 & 2 & 3 & 4 & 5\end{array}$}

DAY

Describe any significant activities that occurred today.

How did the experiences today affect you academically and personally?

What did you learn about peers today?

How did your activities today relate to your overall goals? 
Is there anything you would do differently today?

What is your goal(s) for tomorrow?

Rate your overall professional experience today (1) poor to (5) great!

Rate your overall academic experience today from (1) poor to (5) great!

Rate your communication skills today from (1) poor to (5) great! 


\section{SELF-DEVELOPMENT \\ DAILY JOURNAL}

On a scale of $1-5$,

circle the number

that best fits your

thoughts from

strongly disagree (1)

to strongly agree (5)

I am contributing to my professional development.

$$
\begin{array}{lllll}
1 & 2 & 3 & 4 & 5
\end{array}
$$

College allows me to gain a new perspective on my role in life.

\section{$\begin{array}{lllll}1 & 2 & 3 & 4 & 5\end{array}$}

College helps me learn through direct "hands on" experience.

\section{$\begin{array}{lllll}1 & 2 & 3 & 4 & 5\end{array}$}

I feel the college experience will make a difference when working with coworkers, clients, and the community.

$$
\begin{array}{lllll}
1 & 2 & 3 & 4 & 5
\end{array}
$$

I am able to understand my professional role better through the college experience.

\section{$\begin{array}{lllll}1 & 2 & 3 & 4 & 5\end{array}$}

DAY

Describe any significant activities that occurred today.

How did the experiences today affect you academically and personally?

What did you learn about peers today?

How did your activities today relate to your overall goals? 
Is there anything you would do differently today?

What is your goal(s) for tomorrow?

Rate your overall professional experience today (1) poor to (5) great!

Rate your overall academic experience today from (1) poor to (5) great!

Rate your communication skills today from (1) poor to (5) great! 


\section{SELF-DEVELOPMENT \\ DAILY JOURNAL}

On a scale of $1-5$,

circle the number

that best fits your

thoughts from

strongly disagree (1)

to strongly agree (5)

I am contributing to my professional development.

$$
\begin{array}{lllll}
1 & 2 & 3 & 4 & 5
\end{array}
$$

College allows me to gain a new perspective on my role in life.

\section{$\begin{array}{lllll}1 & 2 & 3 & 4 & 5\end{array}$}

College helps me learn through direct "hands on" experience.

\section{$\begin{array}{lllll}1 & 2 & 3 & 4 & 5\end{array}$}

I feel the college experience will make a difference when working with coworkers, clients, and the community.

$$
\begin{array}{lllll}
1 & 2 & 3 & 4 & 5
\end{array}
$$

I am able to understand my professional role better through the college experience.

\section{$\begin{array}{lllll}1 & 2 & 3 & 4 & 5\end{array}$}

DAY

Describe any significant activities that occurred today.

How did the experiences today affect you academically and personally?

What did you learn about peers today?

How did your activities today relate to your overall goals? 
Is there anything you would do differently today?

What is your goal(s) for tomorrow?

Rate your overall professional experience today (1) poor to (5) great!

Rate your overall academic experience today from (1) poor to (5) great!

Rate your communication skills today from (1) poor to (5) great! 


\section{SELF-DEVELOPMENT \\ DAILY JOURNAL}

On a scale of $1-5$,

circle the number

that best fits your

thoughts from

strongly disagree (1)

to strongly agree (5)

I am contributing to my professional development.

$$
\begin{array}{lllll}
1 & 2 & 3 & 4 & 5
\end{array}
$$

College allows me to gain a new perspective on my role in life.

\section{$\begin{array}{lllll}1 & 2 & 3 & 4 & 5\end{array}$}

College helps me learn through direct "hands on" experience.

\section{$\begin{array}{lllll}1 & 2 & 3 & 4 & 5\end{array}$}

I feel the college experience will make a difference when working with coworkers, clients, and the community.

$$
\begin{array}{lllll}
1 & 2 & 3 & 4 & 5
\end{array}
$$

I am able to understand my professional role better through the college experience.

\section{$\begin{array}{lllll}1 & 2 & 3 & 4 & 5\end{array}$}

DAY

Describe any significant activities that occurred today.

How did the experiences today affect you academically and personally?

What did you learn about peers today?

How did your activities today relate to your overall goals? 
Is there anything you would do differently today?

What is your goal(s) for tomorrow?

Rate your overall professional experience today (1) poor to (5) great!

Rate your overall academic experience today from (1) poor to (5) great!

Rate your communication skills today from (1) poor to (5) great! 


\section{SELF-DEVELOPMENT \\ DAILY JOURNAL}

On a scale of $1-5$,

circle the number

that best fits your

thoughts from

strongly disagree (1)

to strongly agree (5)

I am contributing to my professional development.

$$
\begin{array}{lllll}
1 & 2 & 3 & 4 & 5
\end{array}
$$

College allows me to gain a new perspective on my role in life.

\section{$\begin{array}{lllll}1 & 2 & 3 & 4 & 5\end{array}$}

College helps me learn through direct "hands on" experience.

\section{$\begin{array}{lllll}1 & 2 & 3 & 4 & 5\end{array}$}

I feel the college experience will make a difference when working with coworkers, clients, and the community.

$$
\begin{array}{lllll}
1 & 2 & 3 & 4 & 5
\end{array}
$$

I am able to understand my professional role better through the college experience.

\section{$\begin{array}{lllll}1 & 2 & 3 & 4 & 5\end{array}$}

DAY

Describe any significant activities that occurred today.

How did the experiences today affect you academically and personally?

What did you learn about peers today?

How did your activities today relate to your overall goals? 
Is there anything you would do differently today?

What is your goal(s) for tomorrow?

Rate your overall professional experience today (1) poor to (5) great!

Rate your overall academic experience today from (1) poor to (5) great!

Rate your communication skills today from (1) poor to (5) great! 


\section{SELF-DEVELOPMENT \\ DAILY JOURNAL}

On a scale of $1-5$,

circle the number

that best fits your

thoughts from

strongly disagree (1)

to strongly agree (5)

I am contributing to my professional development.

$$
\begin{array}{lllll}
1 & 2 & 3 & 4 & 5
\end{array}
$$

College allows me to gain a new perspective on my role in life.

\section{$\begin{array}{lllll}1 & 2 & 3 & 4 & 5\end{array}$}

College helps me learn through direct "hands on" experience.

\section{$\begin{array}{lllll}1 & 2 & 3 & 4 & 5\end{array}$}

I feel the college experience will make a difference when working with coworkers, clients, and the community.

$$
\begin{array}{lllll}
1 & 2 & 3 & 4 & 5
\end{array}
$$

I am able to understand my professional role better through the college experience.

\section{$\begin{array}{lllll}1 & 2 & 3 & 4 & 5\end{array}$}

DAY

Describe any significant activities that occurred today.

How did the experiences today affect you academically and personally?

What did you learn about peers today?

How did your activities today relate to your overall goals? 
Is there anything you would do differently today?

What is your goal(s) for tomorrow?

Rate your overall professional experience today (1) poor to (5) great!

Rate your overall academic experience today from (1) poor to (5) great!

Rate your communication skills today from (1) poor to (5) great! 


\section{SELF-DEVELOPMENT \\ DAILY JOURNAL}

On a scale of $1-5$,

circle the number

that best fits your

thoughts from

strongly disagree (1)

to strongly agree (5)

I am contributing to my professional development.

$$
\begin{array}{lllll}
1 & 2 & 3 & 4 & 5
\end{array}
$$

College allows me to gain a new perspective on my role in life.

\section{$\begin{array}{lllll}1 & 2 & 3 & 4 & 5\end{array}$}

College helps me learn through direct "hands on" experience.

\section{$\begin{array}{lllll}1 & 2 & 3 & 4 & 5\end{array}$}

I feel the college experience will make a difference when working with coworkers, clients, and the community.

$$
\begin{array}{lllll}
1 & 2 & 3 & 4 & 5
\end{array}
$$

I am able to understand my professional role better through the college experience.

\section{$\begin{array}{lllll}1 & 2 & 3 & 4 & 5\end{array}$}

DAY

Describe any significant activities that occurred today.

How did the experiences today affect you academically and personally?

What did you learn about peers today?

How did your activities today relate to your overall goals? 
Is there anything you would do differently today?

What is your goal(s) for tomorrow?

Rate your overall professional experience today (1) poor to (5) great!

Rate your overall academic experience today from (1) poor to (5) great!

Rate your communication skills today from (1) poor to (5) great! 


\section{SELF-DEVELOPMENT \\ DAILY JOURNAL}

On a scale of $1-5$,

circle the number

that best fits your

thoughts from

strongly disagree (1)

to strongly agree (5)

I am contributing to my professional development.

$$
\begin{array}{lllll}
1 & 2 & 3 & 4 & 5
\end{array}
$$

College allows me to gain a new perspective on my role in life.

\section{$\begin{array}{lllll}1 & 2 & 3 & 4 & 5\end{array}$}

College helps me learn through direct "hands on" experience.

\section{$\begin{array}{lllll}1 & 2 & 3 & 4 & 5\end{array}$}

I feel the college experience will make a difference when working with coworkers, clients, and the community.

$$
\begin{array}{lllll}
1 & 2 & 3 & 4 & 5
\end{array}
$$

I am able to understand my professional role better through the college experience.

\section{$\begin{array}{lllll}1 & 2 & 3 & 4 & 5\end{array}$}

DAY

Describe any significant activities that occurred today.

How did the experiences today affect you academically and personally?

What did you learn about peers today?

How did your activities today relate to your overall goals? 
Is there anything you would do differently today?

What is your goal(s) for tomorrow?

Rate your overall professional experience today (1) poor to (5) great!

Rate your overall academic experience today from (1) poor to (5) great!

Rate your communication skills today from (1) poor to (5) great! 


\section{SELF-DEVELOPMENT \\ DAILY JOURNAL}

On a scale of $1-5$,

circle the number

that best fits your

thoughts from

strongly disagree (1)

to strongly agree (5)

I am contributing to my professional development.

$$
\begin{array}{lllll}
1 & 2 & 3 & 4 & 5
\end{array}
$$

College allows me to gain a new perspective on my role in life.

\section{$\begin{array}{lllll}1 & 2 & 3 & 4 & 5\end{array}$}

College helps me learn through direct "hands on" experience.

\section{$\begin{array}{lllll}1 & 2 & 3 & 4 & 5\end{array}$}

I feel the college experience will make a difference when working with coworkers, clients, and the community.

$$
\begin{array}{lllll}
1 & 2 & 3 & 4 & 5
\end{array}
$$

I am able to understand my professional role better through the college experience.

\section{$\begin{array}{lllll}1 & 2 & 3 & 4 & 5\end{array}$}

DAY

Describe any significant activities that occurred today.

How did the experiences today affect you academically and personally?

What did you learn about peers today?

How did your activities today relate to your overall goals? 
Is there anything you would do differently today?

What is your goal(s) for tomorrow?

Rate your overall professional experience today (1) poor to (5) great!

Rate your overall academic experience today from (1) poor to (5) great!

Rate your communication skills today from (1) poor to (5) great! 


\section{SELF-DEVELOPMENT \\ DAILY JOURNAL}

On a scale of $1-5$,

circle the number

that best fits your

thoughts from

strongly disagree (1)

to strongly agree (5)

I am contributing to my professional development.

$$
\begin{array}{lllll}
1 & 2 & 3 & 4 & 5
\end{array}
$$

College allows me to gain a new perspective on my role in life.

\section{$\begin{array}{lllll}1 & 2 & 3 & 4 & 5\end{array}$}

College helps me learn through direct "hands on" experience.

\section{$\begin{array}{lllll}1 & 2 & 3 & 4 & 5\end{array}$}

I feel the college experience will make a difference when working with coworkers, clients, and the community.

$$
\begin{array}{lllll}
1 & 2 & 3 & 4 & 5
\end{array}
$$

I am able to understand my professional role better through the college experience.

\section{$\begin{array}{lllll}1 & 2 & 3 & 4 & 5\end{array}$}

DAY

Describe any significant activities that occurred today.

How did the experiences today affect you academically and personally?

What did you learn about peers today?

How did your activities today relate to your overall goals? 
Is there anything you would do differently today?

What is your goal(s) for tomorrow?

Rate your overall professional experience today (1) poor to (5) great!

Rate your overall academic experience today from (1) poor to (5) great!

Rate your communication skills today from (1) poor to (5) great! 


\section{SELF-DEVELOPMENT \\ DAILY JOURNAL}

On a scale of $1-5$,

circle the number

that best fits your

thoughts from

strongly disagree (1)

to strongly agree (5)

I am contributing to my professional development.

$$
\begin{array}{lllll}
1 & 2 & 3 & 4 & 5
\end{array}
$$

College allows me to gain a new perspective on my role in life.

\section{$\begin{array}{lllll}1 & 2 & 3 & 4 & 5\end{array}$}

College helps me learn through direct "hands on" experience.

\section{$\begin{array}{lllll}1 & 2 & 3 & 4 & 5\end{array}$}

I feel the college experience will make a difference when working with coworkers, clients, and the community.

$$
\begin{array}{lllll}
1 & 2 & 3 & 4 & 5
\end{array}
$$

I am able to understand my professional role better through the college experience.

\section{$\begin{array}{lllll}1 & 2 & 3 & 4 & 5\end{array}$}

DAY

Describe any significant activities that occurred today.

How did the experiences today affect you academically and personally?

What did you learn about peers today?

How did your activities today relate to your overall goals? 
Is there anything you would do differently today?

What is your goal(s) for tomorrow?

Rate your overall professional experience today (1) poor to (5) great!

Rate your overall academic experience today from (1) poor to (5) great!

Rate your communication skills today from (1) poor to (5) great! 


\section{SELF-DEVELOPMENT \\ DAILY JOURNAL}

On a scale of $1-5$,

circle the number

that best fits your

thoughts from

strongly disagree (1)

to strongly agree (5)

I am contributing to my professional development.

$$
\begin{array}{lllll}
1 & 2 & 3 & 4 & 5
\end{array}
$$

College allows me to gain a new perspective on my role in life.

\section{$\begin{array}{lllll}1 & 2 & 3 & 4 & 5\end{array}$}

College helps me learn through direct "hands on" experience.

\section{$\begin{array}{lllll}1 & 2 & 3 & 4 & 5\end{array}$}

I feel the college experience will make a difference when working with coworkers, clients, and the community.

$$
\begin{array}{lllll}
1 & 2 & 3 & 4 & 5
\end{array}
$$

I am able to understand my professional role better through the college experience.

\section{$\begin{array}{lllll}1 & 2 & 3 & 4 & 5\end{array}$}

DAY

Describe any significant activities that occurred today.

How did the experiences today affect you academically and personally?

What did you learn about peers today?

How did your activities today relate to your overall goals? 
Is there anything you would do differently today?

What is your goal(s) for tomorrow?

Rate your overall professional experience today (1) poor to (5) great!

Rate your overall academic experience today from (1) poor to (5) great!

Rate your communication skills today from (1) poor to (5) great! 


\section{SELF-DEVELOPMENT \\ DAILY JOURNAL}

On a scale of $1-5$,

circle the number

that best fits your

thoughts from

strongly disagree (1)

to strongly agree (5)

I am contributing to my professional development.

$$
\begin{array}{lllll}
1 & 2 & 3 & 4 & 5
\end{array}
$$

College allows me to gain a new perspective on my role in life.

\section{$\begin{array}{lllll}1 & 2 & 3 & 4 & 5\end{array}$}

College helps me learn through direct "hands on" experience.

\section{$\begin{array}{lllll}1 & 2 & 3 & 4 & 5\end{array}$}

I feel the college experience will make a difference when working with coworkers, clients, and the community.

$$
\begin{array}{lllll}
1 & 2 & 3 & 4 & 5
\end{array}
$$

I am able to understand my professional role better through the college experience.

\section{$\begin{array}{lllll}1 & 2 & 3 & 4 & 5\end{array}$}

DAY

Describe any significant activities that occurred today.

How did the experiences today affect you academically and personally?

What did you learn about peers today?

How did your activities today relate to your overall goals? 
Is there anything you would do differently today?

What is your goal(s) for tomorrow?

Rate your overall professional experience today (1) poor to (5) great!

Rate your overall academic experience today from (1) poor to (5) great!

Rate your communication skills today from (1) poor to (5) great! 


\section{SELF-DEVELOPMENT \\ DAILY JOURNAL}

On a scale of $1-5$,

circle the number

that best fits your

thoughts from

strongly disagree (1)

to strongly agree (5)

I am contributing to my professional development.

$$
\begin{array}{lllll}
1 & 2 & 3 & 4 & 5
\end{array}
$$

College allows me to gain a new perspective on my role in life.

\section{$\begin{array}{lllll}1 & 2 & 3 & 4 & 5\end{array}$}

College helps me learn through direct "hands on" experience.

\section{$\begin{array}{lllll}1 & 2 & 3 & 4 & 5\end{array}$}

I feel the college experience will make a difference when working with coworkers, clients, and the community.

$$
\begin{array}{lllll}
1 & 2 & 3 & 4 & 5
\end{array}
$$

I am able to understand my professional role better through the college experience.

\section{$\begin{array}{lllll}1 & 2 & 3 & 4 & 5\end{array}$}

DAY

Describe any significant activities that occurred today.

How did the experiences today affect you academically and personally?

What did you learn about peers today?

How did your activities today relate to your overall goals? 
Is there anything you would do differently today?

What is your goal(s) for tomorrow?

Rate your overall professional experience today (1) poor to (5) great!

Rate your overall academic experience today from (1) poor to (5) great!

Rate your communication skills today from (1) poor to (5) great! 


\section{SELF-DEVELOPMENT \\ DAILY JOURNAL}

On a scale of $1-5$,

circle the number

that best fits your

thoughts from

strongly disagree (1)

to strongly agree (5)

I am contributing to my professional development.

$$
\begin{array}{lllll}
1 & 2 & 3 & 4 & 5
\end{array}
$$

College allows me to gain a new perspective on my role in life.

\section{$\begin{array}{lllll}1 & 2 & 3 & 4 & 5\end{array}$}

College helps me learn through direct "hands on" experience.

\section{$\begin{array}{lllll}1 & 2 & 3 & 4 & 5\end{array}$}

I feel the college experience will make a difference when working with coworkers, clients, and the community.

$$
\begin{array}{lllll}
1 & 2 & 3 & 4 & 5
\end{array}
$$

I am able to understand my professional role better through the college experience.

\section{$\begin{array}{lllll}1 & 2 & 3 & 4 & 5\end{array}$}

DAY

Describe any significant activities that occurred today.

How did the experiences today affect you academically and personally?

What did you learn about peers today?

How did your activities today relate to your overall goals? 
Is there anything you would do differently today?

What is your goal(s) for tomorrow?

Rate your overall professional experience today (1) poor to (5) great!

Rate your overall academic experience today from (1) poor to (5) great!

Rate your communication skills today from (1) poor to (5) great! 


\section{SELF-DEVELOPMENT \\ DAILY JOURNAL}

On a scale of $1-5$,

circle the number

that best fits your

thoughts from

strongly disagree (1)

to strongly agree (5)

I am contributing to my professional development.

$$
\begin{array}{lllll}
1 & 2 & 3 & 4 & 5
\end{array}
$$

College allows me to gain a new perspective on my role in life.

\section{$\begin{array}{lllll}1 & 2 & 3 & 4 & 5\end{array}$}

College helps me learn through direct "hands on" experience.

\section{$\begin{array}{lllll}1 & 2 & 3 & 4 & 5\end{array}$}

I feel the college experience will make a difference when working with coworkers, clients, and the community.

$$
\begin{array}{lllll}
1 & 2 & 3 & 4 & 5
\end{array}
$$

I am able to understand my professional role better through the college experience.

\section{$\begin{array}{lllll}1 & 2 & 3 & 4 & 5\end{array}$}

DAY

Describe any significant activities that occurred today.

How did the experiences today affect you academically and personally?

What did you learn about peers today?

How did your activities today relate to your overall goals? 
Is there anything you would do differently today?

What is your goal(s) for tomorrow?

Rate your overall professional experience today (1) poor to (5) great!

Rate your overall academic experience today from (1) poor to (5) great!

Rate your communication skills today from (1) poor to (5) great! 


\section{SELF-DEVELOPMENT \\ DAILY JOURNAL}

On a scale of $1-5$,

circle the number

that best fits your

thoughts from

strongly disagree (1)

to strongly agree (5)

I am contributing to my professional development.

$$
\begin{array}{lllll}
1 & 2 & 3 & 4 & 5
\end{array}
$$

College allows me to gain a new perspective on my role in life.

\section{$\begin{array}{lllll}1 & 2 & 3 & 4 & 5\end{array}$}

College helps me learn through direct "hands on" experience.

\section{$\begin{array}{lllll}1 & 2 & 3 & 4 & 5\end{array}$}

I feel the college experience will make a difference when working with coworkers, clients, and the community.

$$
\begin{array}{lllll}
1 & 2 & 3 & 4 & 5
\end{array}
$$

I am able to understand my professional role better through the college experience.

\section{$\begin{array}{lllll}1 & 2 & 3 & 4 & 5\end{array}$}

DAY

Describe any significant activities that occurred today.

How did the experiences today affect you academically and personally?

What did you learn about peers today?

How did your activities today relate to your overall goals? 
Is there anything you would do differently today?

What is your goal(s) for tomorrow?

Rate your overall professional experience today (1) poor to (5) great!

Rate your overall academic experience today from (1) poor to (5) great!

Rate your communication skills today from (1) poor to (5) great! 


\section{SELF-DEVELOPMENT \\ DAILY JOURNAL}

On a scale of $1-5$,

circle the number

that best fits your

thoughts from

strongly disagree (1)

to strongly agree (5)

I am contributing to my professional development.

$$
\begin{array}{lllll}
1 & 2 & 3 & 4 & 5
\end{array}
$$

College allows me to gain a new perspective on my role in life.

\section{$\begin{array}{lllll}1 & 2 & 3 & 4 & 5\end{array}$}

College helps me learn through direct "hands on" experience.

\section{$\begin{array}{lllll}1 & 2 & 3 & 4 & 5\end{array}$}

I feel the college experience will make a difference when working with coworkers, clients, and the community.

$$
\begin{array}{lllll}
1 & 2 & 3 & 4 & 5
\end{array}
$$

I am able to understand my professional role better through the college experience.

\section{$\begin{array}{lllll}1 & 2 & 3 & 4 & 5\end{array}$}

DAY

Describe any significant activities that occurred today.

How did the experiences today affect you academically and personally?

What did you learn about peers today?

How did your activities today relate to your overall goals? 
Is there anything you would do differently today?

What is your goal(s) for tomorrow?

Rate your overall professional experience today (1) poor to (5) great!

Rate your overall academic experience today from (1) poor to (5) great!

Rate your communication skills today from (1) poor to (5) great! 


\section{SELF-DEVELOPMENT \\ DAILY JOURNAL}

On a scale of $1-5$,

circle the number

that best fits your

thoughts from

strongly disagree (1)

to strongly agree (5)

I am contributing to my professional development.

$$
\begin{array}{lllll}
1 & 2 & 3 & 4 & 5
\end{array}
$$

College allows me to gain a new perspective on my role in life.

\section{$\begin{array}{lllll}1 & 2 & 3 & 4 & 5\end{array}$}

College helps me learn through direct "hands on" experience.

\section{$\begin{array}{lllll}1 & 2 & 3 & 4 & 5\end{array}$}

I feel the college experience will make a difference when working with coworkers, clients, and the community.

$$
\begin{array}{lllll}
1 & 2 & 3 & 4 & 5
\end{array}
$$

I am able to understand my professional role better through the college experience.

\section{$\begin{array}{lllll}1 & 2 & 3 & 4 & 5\end{array}$}

DAY

Describe any significant activities that occurred today.

How did the experiences today affect you academically and personally?

What did you learn about peers today?

How did your activities today relate to your overall goals? 
Is there anything you would do differently today?

What is your goal(s) for tomorrow?

Rate your overall professional experience today (1) poor to (5) great!

Rate your overall academic experience today from (1) poor to (5) great!

Rate your communication skills today from (1) poor to (5) great! 


\section{SELF-DEVELOPMENT \\ DAILY JOURNAL}

On a scale of $1-5$,

circle the number

that best fits your

thoughts from

strongly disagree (1)

to strongly agree (5)

I am contributing to my professional development.

$$
\begin{array}{lllll}
1 & 2 & 3 & 4 & 5
\end{array}
$$

College allows me to gain a new perspective on my role in life.

\section{$\begin{array}{lllll}1 & 2 & 3 & 4 & 5\end{array}$}

College helps me learn through direct "hands on" experience.

\section{$\begin{array}{lllll}1 & 2 & 3 & 4 & 5\end{array}$}

I feel the college experience will make a difference when working with coworkers, clients, and the community.

$$
\begin{array}{lllll}
1 & 2 & 3 & 4 & 5
\end{array}
$$

I am able to understand my professional role better through the college experience.

\section{$\begin{array}{lllll}1 & 2 & 3 & 4 & 5\end{array}$}

DAY

Describe any significant activities that occurred today.

How did the experiences today affect you academically and personally?

What did you learn about peers today?

How did your activities today relate to your overall goals? 
Is there anything you would do differently today?

What is your goal(s) for tomorrow?

Rate your overall professional experience today (1) poor to (5) great!

Rate your overall academic experience today from (1) poor to (5) great!

Rate your communication skills today from (1) poor to (5) great! 


\section{END OF THE YEAR SELF-ANALYSIS}

Question/thoughts to ponder:

- Define your last year and the purpose.

- Define what activities you performed and with whom.

- What did those experiences mean to you?

- Have your goals changed from the beginning of your journaling till now?

- Did any academic information you learned help you with your current job?

- Is there anything you learned that was unexpected? Explain.

- Did you accomplish everything you set out to do? 


\section{OVERALL REFLECTION}

1. How satisfied were you with the last year?

2. Did you learn what you expected to learn?

3. What important things did you learn? Was that mainly in the classroom, at different events, etc?

4. How do you think this last year related to your career path? Explain.

5. Do you think this last academic year related to your future job's objectives and duties? Explain.

6. Did you have culture shock?

7. If you did have culture shock, how did you manage it? 
8. Were you able to communicate effectively with other students? Faculty?

9. Did you notice any particular nonverbal actions and/or gestures different from your own? What were they?

10. Is there anyone you talked to about your experiences in the last year?

11. What did you learn about your college?

12. How are you feeling right now about your college experience?

13. Is there anything you will do differently in the next year? 


\section{NOTES}


For more information, please contact Margaret Sass at sassm@purdue.edu.

By Margaret Shu-Mei Sass C 2013 